Article

\title{
Live-Scale Testing of Granular Materials Stabilized with Alkali-Activated Waste Glass and Carbide Lime
}

\author{
Marina Paula Secco ${ }^{1, *(\mathbb{D}}$, Débora Thaís Mesavilla ${ }^{1} \mathbb{D}$, Márcio Felipe Floss ${ }^{2}$, Nilo Cesar Consoli ${ }^{1}$ (D), \\ Tiago Miranda ${ }^{3}$ and Nuno Cristelo ${ }^{4}$ (D) \\ 1 Civil Engineering, Federal University of Rio Grande do Sul, Porto Alegre 90035-190, Brazil; \\ d.t.mesavilla@hotmail.com (D.T.M.); consoli@ufrgs.br (N.C.C.) \\ 2 Civil and Environmental Engineering, University of Passo Fundo, Passo Fundo 99052-900, Brazil; \\ marciofloss@upf.br \\ 3 School of Engineering, University of Minho, 4800-058 Guimarães, Portugal; tmiranda@civil.uminho.pt \\ 4 Department of Engineering, University of Trás-os-Montes e Alto Douro, 5000-801 Vila Real, Portugal; \\ ncristel@utad.pt \\ * Correspondence: marinapaula.secco@hotmail.com; Tel.: +351-913-674-448
}

\section{check for} updates

Citation: Secco, M.P.; Mesavilla, D.T.; Floss, M.F.; Cesar Consoli, N.; Miranda, T.; Cristelo, N. Live-Scale Testing of Granular Materials Stabilized with Alkali-Activated Waste Glass and Carbide Lime. Appl. Sci. 2021, 11, 11286. https://doi.org/ 10.3390/app112311286

Academic Editors: Luís

Filipe Almeida Bernardo and Sérgio

Manuel Rodrigues Lopes

Received: 15 October 2021

Accepted: 23 November 2021

Published: 29 November 2021

Publisher's Note: MDPI stays neutral with regard to jurisdictional claims in published maps and institutional affiliations.

Copyright: (c) 2021 by the authors. Licensee MDPI, Basel, Switzerland. This article is an open access article distributed under the terms and conditions of the Creative Commons Attribution (CC BY) license (https:// creativecommons.org/licenses/by/ $4.0 /)$.
Abstract: The increasingly strong search for alternative materials to Portland cement has resulted in the development of alkali-activated cements (AAC) that are very effective at using industrial byproducts as raw materials, which also contributes to the volume reduction in landfilled waste. Several studies targeting the development of AAC — based on wastes containing silicon and calcium-for chemical stabilization of soils have demonstrated their excellent performance in terms of durability and mechanical performance. However, most of these studies are confined to a laboratory characterization, ignoring the influence and viability of the in situ construction process and, also important, of the in situ curing conditions. The present work investigated the field application of an AAC based on carbide lime and glass wastes to stabilize fine sand acting as a superficial foundation. The assessment was supported on the unconfined compressive strength (UCS) and initial shear modulus $\left(\mathrm{G}_{0}\right)$ of the developed material, and the field results were compared with those prepared in the laboratory, up to 120 days curing. In situ tests were also developed on the field layers (with diameters of 450 and $900 \mathrm{~mm}$ and thickness of $300 \mathrm{~mm}$ ) after different curing times. To establish a reference, the mentioned precursors were either activated with a sodium hydroxide solution or hydrated with water (given the reactivity of the lime). The results showed that the AAC-based mixtures developed greater strength and stiffness at a faster rate than the water-based mixtures. Specimens cured under controlled laboratory conditions showed better results than the samples collected in the field. The inclusion of the stabilized layers clearly increased the load-bearing capacity of the natural soil, while the different diameters produced different failure mechanisms, similar to those found in Portland cement stabilization.

Keywords: geotechnical engineering; ground improvement; alkali-activated cements; recycling and reuse of materials

\section{Introduction}

A recurrent problem found in engineering works is the poor geomechanical properties and, especially, the low strength and stiffness of soils, which is responsible for the structural problems associated with the installation of superficial foundations or pavement layers, for example, often made unfeasible. In North and South America, the main parameter that regulates paving applications is the unconfined compressive strength $\left(q_{u}\right)$, which must be >1.2 MPa for sub-base layers and 2.1 MPa for base layers [1]. The minimum required values for $q_{u}$ are 1.7, 4.5 and 4.7 MPa in sub-base and base layers of pavements constructed in Australia, India and Korea, respectively [2]. In Brazil, the standards establish minimum $q_{u}$ values of 1.2 and $2.1 \mathrm{MPa}$ for the material to be applied on sub-base and base layers, respectively [3]. 
A widely used solution to the problem of soils with low bearing capacity is the modification of the original geotechnical properties of the existing soil by creating what can be considered a new material. This is achieved through the addition of a cementitious agent, usually Portland cement [4-11]. However, the production of ordinary Portland cement (OPC) imposes a very significant toll on the environment [12] since it is one of the world's most energy-intensive industrial processes, contributing to around $7 \%$ of the world's total $\mathrm{CO}_{2}$ emissions $[13,14]$. During the intensive search for alternative binders to OPC, alkaline-activated cements (AAC) are rapidly gaining ground, as it involves mostly industrial wastes, and the results are competitive with those produced by OPC. Despite being a recent technique, many studies on alkali-activation of wastes have already shown several advantages of these alternative materials, from high compressive strengths, low shrinkage levels, acid and fire resistance and low thermal conductivity [15-23].

Alkaline activation is, in general terms [24-27], a reaction that occurs when materials rich in silica $\left(\mathrm{SiO}_{2}\right)$ and alumina $\left(\mathrm{AlO}_{4}\right)$ come into contact with a highly alkaline medium which is usually provided by alkaline substances such as sodium $\left(\mathrm{Na}^{+}\right)$or potassium $\left(\mathrm{K}^{+}\right)$. These alkaline substances initially increase the $\mathrm{pH}$ of the medium, accelerating the solubility and promoting the dissolution of elements such as silica and alumina present in the material; that is, there is a phase of breaking the ionic and covalent bonds of the vitreous phase of the raw material and then silica and alumina colloids are released into the solution forming a coagulated structure (gel) favoring then condensation reactions that lead, finally, to the polymerization of the structure resulting in compounds with greater resistance to compression. If calcium is present in the mixture in significant amounts, the dissolved Al-Si complex will diffuse from the solid surface and produce a dominant $\mathrm{C}-\mathrm{S}-\mathrm{H}$ gel phase. If calcium is present in the mixture in significant quantities, the dissolved $\mathrm{Al}-\mathrm{Si}$ complex will diffuse from the solid surface and produce a dominant $\mathrm{C}-\mathrm{S}-\mathrm{H}$ gel phase.

The use of industrial waste and/or by-products as precursors for the development of AAC was shown to be a highly viable alternative to replace Portland cement in civil construction, presenting not only excellent performance in terms of mechanical characteristics but also several advantages from an environmental perspective. In addition to contributing to a reduction in $\mathrm{CO}_{2}$ emissions caused by Portland cement industry, AACs contribute to the preservation of non-renewable natural resources utilized in Portland cement production. The incorporation of industrial waste as raw material in binders allows its reintroduction into the economy, avoiding its disposal in landfills, which may reduce environmental contamination [28].

The production of urban and industrial waste has been rapidly increasing worldwide in the last few decades [29]. A strong example is glass, which is essentially an inert material that, under common environmental conditions, can be recycled in many ways without modification of its chemical properties. The collection and recycling of waste glass have thus become very common and inclusive and are now included in the environmental policies in the developed world. However, waste glass must meet a series of requirements for reuse in the manufacture of other glass products. Furthermore, the mixing of different glass types with different chemical compositions and particle sizes is only possible with highly complex technological processes. As a result, in Brazil, only about $47 \%$ of all glass containers were recycled in 2011 for a total of 470 thousand tons; while in the USA, this percentage was even lower, with $40 \%$ in 2015 [30]. This illustrates well the fact that several industrialized countries are still landfilling large volumes of their waste glass, thus requiring alternative valorization possibilities.

Recent studies have explored the pozzolanic properties of waste glass and its application to a new variety of binders, which include the recycling of different types of industrial waste and by-products (i.e., industrial, agricultural and urban), and have gained notability as soil stabilizers in substitute to OPC in soil-cement $[8,17,20,31-34]$.

Glass, in general, has silicon dioxide $\left(\mathrm{SiO}_{2}\right)$ as its main constituent, and the material resulting from its production process (at high temperatures) is a solid with an essentially amorphous framework. Thus, finely ground waste glass obtained from the milling of 
soda-lime glass containers presents a viable alternative source of silica for alkali-activated materials $[13,29,35]$. Such residue has already been used in several researches, combined with hydrated lime, for the stabilization of a variety of soils. These materials were characterized by matching and even improving mechanical performance, both in strength and durability, compared to materials produced from Portland clinker [33,34,36-41].

Recently, ref. [34] evaluated the mechanical performance of the exact same mixture used in this research, i.e., sandy soil amended with an AAC composed of ground waste glass (GWG), carbide lime (CL) and sodium hydroxide $(\mathrm{NaOH})$ with a concentration of 3 molal. The effect of key factors, such as the presence of a $\mathrm{NaOH}$ solution, the dry unit weight and the amount of binder, was evaluated on the unconfined compressive strength $\left(q_{u}\right)$, initial shear modulus $\left(\mathrm{G}_{0}\right)$ and accumulated loss of mass (ALM). Higher values of $q_{u}$ were evidenced with less porous specimens containing greater amounts of binder (around 2.0 MPa). The authors concluded that this high performance is associated with the reaction mechanism (polymerization-condensation) in which the cementitious reaction products are formed in these high alkalinity media. [39], through compressive strength and durability tests, concluded that the compacted mixture of finely ground waste glass-carbide lime with an alkaline sodium hydroxide solution of 3 molal concentration has proven to be a viable material to be used in engineering applications as an alternative and sustainable replacement geomaterial for earthworks, pavement and soil stabilization. Finally, ref. [41] used calcium carbide residue (CL) to alkali-activate recycled glass powder (RGP) and improve the mechanical properties of clay soil, finding significant values of compressive strength (higher than $2 \mathrm{MPa}$ ) for the GP content of $15 \%$ and CL 7\%, by weight.

However, most of the mentioned research on the use of alternative binders for soil stabilization is still, and only, focused on laboratory characterization, while the viability and impact of the construction process associated with these alternative solutions, as well as the effect of in situ curing conditions on the mechanical properties of the stabilized soil, requires live-scale field tests.

Recently, ref. [37] presented a study addressing the use of an alternative cement based on glass and carbide lime waste (without the addition of an alkaline solution) to stabilize fine sand and evaluate its use in the field as a reinforced layer underneath superficial foundation. The failure mechanisms presented were very similar to those found in similar studies using Portland cement. However, no field studies were found in the literature that addressed the implications of adding an alkaline solution to activate these precursors (glass and carbide lime waste). Thus, the present study is, to the best of the authors' knowledge, the first full-scale assessment of the application of an alternative cement based on ground glass waste (GWG) and carbide lime waste (CL) activated with an alkaline solution of sodium hydroxide (SHS) to the stabilize the fine sand. After the laboratory evaluation of the binders, several layers of fine sand were stabilized with two different types of bindersboth based on GWG and CL, which were alkali-activated in one case and hydrated with water in the other-and analyzed after 14 and 120 days of curing, through their unconfined compressive strength (UCS) and initial shear modulus material stiffness $\left(\mathrm{G}_{0}\right)$. These tests were performed on samples collected in the field, and the results obtained were compared with those from the specimens of the same material, fabricated in the controlled laboratory conditions. The evolution of the mechanical behavior of these materials in controlled laboratory conditions is presented throughout the curing period, up to a maximum of 120 days. Finally, the results of in situ plate load tests are also presented.

\section{Experimental Program}

\subsection{Materials}

The sand used in this study was originally from the region of Osorio, Southern Brazil. It can be classified, according to the Unified Soil Classification System [42], as poorly graded sand (SP). It is fine quartz sand with rounded-shaped particles and a uniform grain size distribution. The density of the grains is $2.65 \mathrm{~g} / \mathrm{cm}^{3}$, and the maximum and minimum void ratios were 0.6 and 0.9 , respectively. The particle size distribution (Figure 1) shows a 
mean effective diameter $\left(D_{50}\right)$ of $0.16 \mathrm{~mm}$, and the uniformity and curvature coefficients were 1.9 and 1.2, respectively. Physical properties are shown in Table 1.

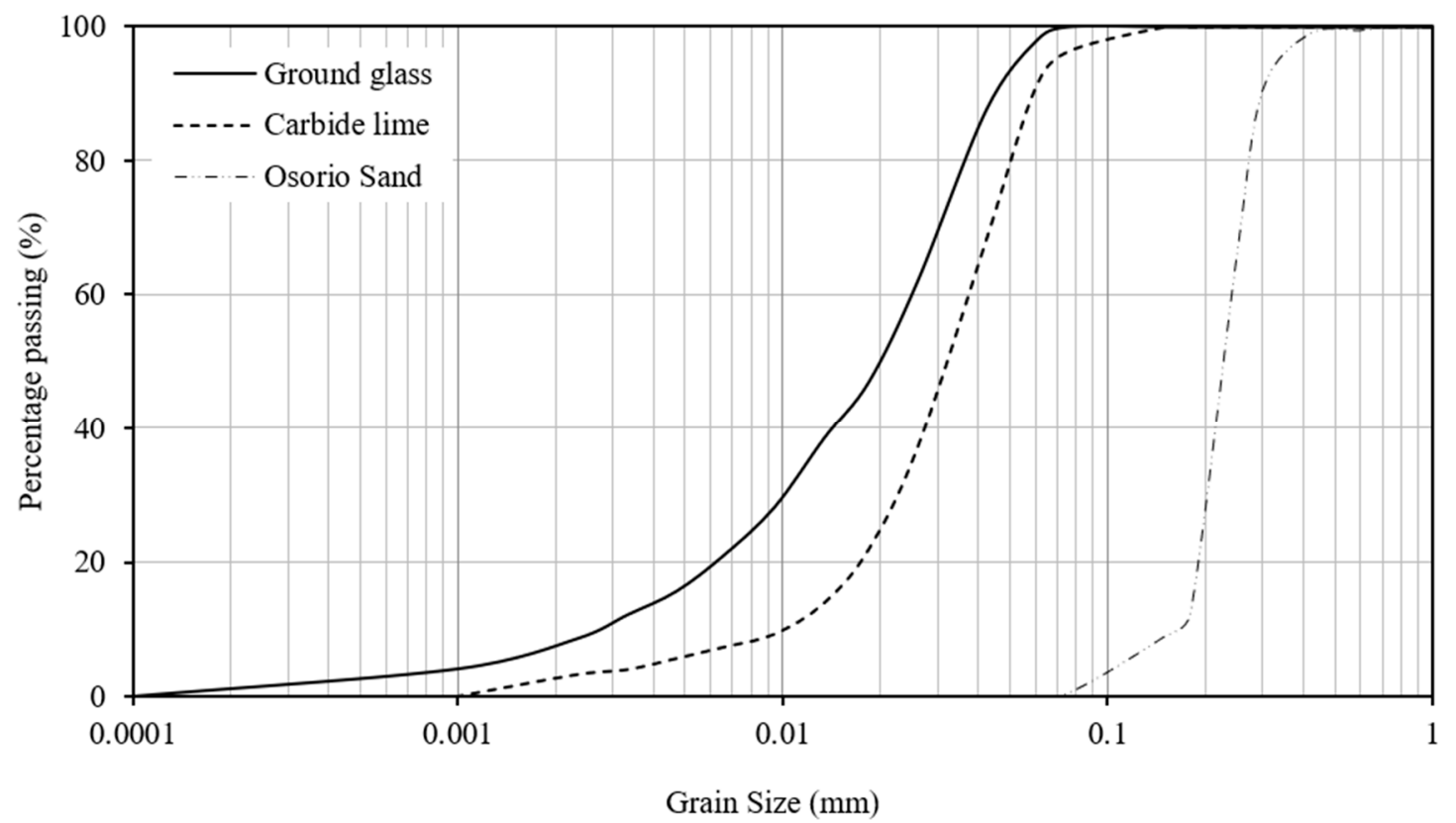

Figure 1. Particle size distribution of ground waste glass, carbide lime and Osorio sand.

Table 1. Physical properties of the Osorio sand, ground waste glass and carbide lime.

\begin{tabular}{cccc}
\hline Properties & $\begin{array}{c}\text { Osorio } \\
\text { Sand }\end{array}$ & GWG & CL \\
\hline Specific gravity $\left(\mathrm{g} / \mathrm{cm}^{3}\right)$ & 2.65 & 2.47 & 2.19 \\
$(\%)$ & 1.0 & - & - \\
Medium sand $(0.425 \mathrm{~mm}<$ diameter $<2.0 \mathrm{~mm})$ & 98.8 & 30.6 & 2.0 \\
Fine sand $(0.075 \mathrm{~mm}<$ diameter $<0.425 \mathrm{~mm})(\%)$ & 0.2 & 60.4 & 94.75 \\
Silt $(0.002 \mathrm{~mm}<$ diameter $<0.075 \mathrm{~mm})(\%)$ & 0 & 9.0 & 3.25 \\
Clay $($ diameter $<0.002 \mathrm{~mm})(\%)$ & - & - & - \\
Liquid limit & Non-plastic & Non-plastic & Non-plastic \\
Plastic index & SP & ML & ML \\
\hline Soil classification (ASTM D2487) & & &
\end{tabular}

The GWG, used as a precursor, was derived from the milling of transparent domestic waste glass (i.e., containers and windows) of the soda-lime type in a ball mill. It was classified as a silt material (ML) in terms of particle size [43]. The milling process followed a regular procedure that comprehended a fixed time, a defined quantity of glass waste and a particular quantity of metal balls. Once this process was finished, the resultant glass powder was subjected to a sieving process, with the aim of increasing its chemical reactivity and standardizing the material to a maximum particle size of $0.075 \mathrm{~mm}$ (sieve \# 200) and a specific surface area of $3.28 \mathrm{~cm}^{2} / \mathrm{g}$. The particle size distribution is presented in Figure 1, while the physical properties are shown in Table 1. The chemical composition of the GWG obtained by X-ray fluorescence (XRF) shows a majority content of $\mathrm{SiO}_{2}(69.09 \mathrm{wt} \%)$ (Table 2). X-ray diffraction analysis (Figure 2a) shows the presence of some amorphous content, characterized by the presence of a large hump between 15 and $40\left({ }^{\circ} 2 \theta\right)$ angles, as well as an absence of prominent peaks, indicating that no crystalline phases are present. 
Table 2. Composition of the ground waste glass and carbide lime (wt \%).

\begin{tabular}{ccccccccccc}
\hline Element & $\mathrm{SiO}_{2}$ & $\mathrm{Al}_{2} \mathbf{O}_{3}$ & $\mathrm{Fe}_{2} \mathbf{O}_{3}$ & $\mathbf{C a O}$ & $\mathbf{N a}_{2} \mathbf{O}$ & $\mathbf{M g O}$ & $\mathrm{TiO}_{2}$ & $\mathbf{M n O}$ & $\mathbf{P}_{2} \mathbf{O}_{5}$ & $\mathbf{K}_{\mathbf{2}} \mathbf{O}$ \\
\hline Ground Waste Glass & 69.02 & 4.34 & 0.91 & 9.72 & 10.89 & 4.2 & 0.05 & 0.01 & - & 0.25 \\
Carbide lime & 3.18 & 1.99 & 0.98 & 69.62 & - & 0.56 & 0.08 & 0.01 & 0.01 & - \\
\hline
\end{tabular}
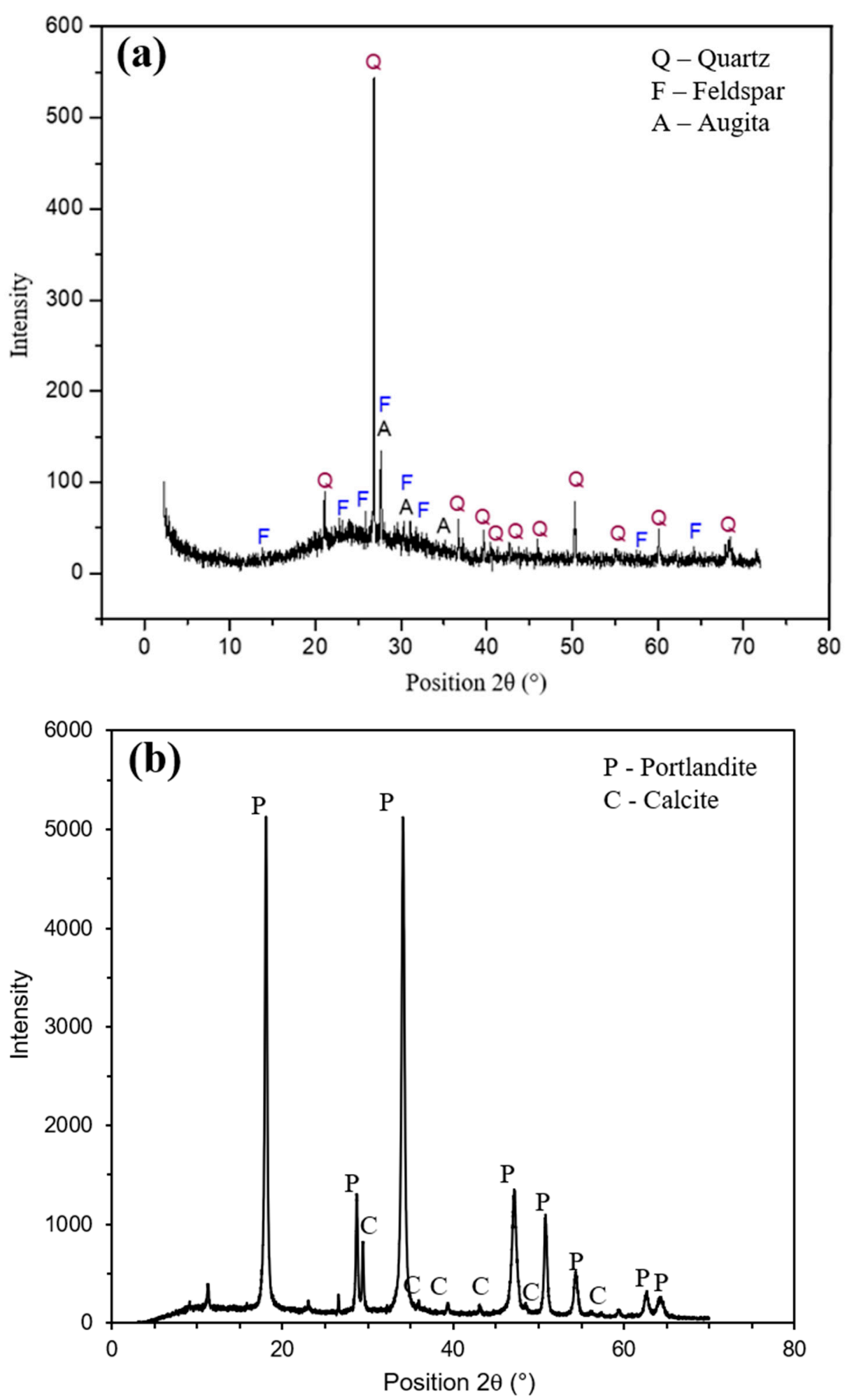

Figure 2. X-ray diffractometry (a) ground waste glass; (b) carbide lime waste. 
The $\mathrm{CL}$ is the residue from the production of acetylene gas, obtained near Porto Alegre city (southern Brazil). This waste was received in the form of agglomerated powder (lumps) due to its high humidity. The $\mathrm{CL}$ was dried for $48 \mathrm{~h}$ at $60^{\circ} \mathrm{C}$ and then ground by hand using a porcelain mortar and sieved to guarantee a maximum size of $0.075 \mathrm{~mm}$. The particle size distribution is presented in Figure 1, and the physical properties are shown in Table 1. The chemical composition (Table 2 ) reveals a significant calcium content $(69.62 \mathrm{wt} \%)$, while the high loss of material $(23.58 \mathrm{wt} \%)$, after calcination at $1000^{\circ} \mathrm{C}$, is mainly due to the presence of calcium carbonate [44,45]. Mineralogically, the XRD (Figure 2b) pattern of the CL shows the main presence of portlandite and crystallized carbonate phases (mainly calcium carbonate-calcite). A complete and detailed physical, chemical and mineralogical characterization of this residue can be encountered in [45].

An SHS was used as an activator. Sodium hydroxide of analytical purity $(99.0 \%)$, in the form of pellets, was dissolved in distilled water to produce the alkaline solution with a concentration of 3 molal. This was based on the literature review of alkaline activation of GWG [16,46-48].

The experimental program was divided into two stages: laboratory-based and fieldbased testing of two different families of binders-those activated with the SHS and those hydrated with water. According to previous laboratory studies, for both sets of mixtures, the GWG content was $30 \%$ of the dry weight of the sand, whereas the CL content was $7 \%$ of the total mass of solids [16]. Therefore, the two binders differ only in their liquid phase:

- $\quad B_{S H S}$ (activated with a 3 molal sodium hydroxide solution);

- $\mathrm{B}_{\mathrm{H} 2 \mathrm{O}}$ (hydrated with water).

All specimens were molded with a water content $(\omega)$ of $11 \%$, for a maximum dry unit weight $\left(\gamma_{d}\right)$ of $16.0 \mathrm{kN} / \mathrm{m}^{3}(e=0.60)$, according to Proctor compaction tests [49]. Although the Proctor compaction tests revealed that higher dry unit weight values could be reached, this value was selected to facilitate the fabrication of the live-scale layers.

\subsection{Fabrication of the Laboratory Specimens}

Cylindrical specimens with $50 \mathrm{~mm}$ in diameter and $100 \mathrm{~mm}$ in height were molded in the laboratory. The molding procedure of the specimens consisted of the following steps: (1) individual weighing of the dry materials (Osorio sand, GWG and CL) in two-digit precision scales; (2) manually mixing of solid materials until visual homogeneity was acquired; (3) addition of solution sodium hydroxide (SHS), or distilled water, followed by manual mixing for $10 \mathrm{~min}$, or until total homogenization; (4) weighing of the pastes according to established parameters; (5) separation of the paste in three small portions, in order to verify the molding moisture content; (6) static compaction in cylindrical molds, considering three sequential layers, with the top of each layer scarified to enhance the adherence to the next layer; (7) weighing and measurement of each specimen, with precisions of $0.01 \mathrm{~g}$ and $0.1 \mathrm{~mm}$, respectively; (8) sealing of the molded sample in a plastic bag. The following molding specifications were observed: Maximum variations of $\pm 1.5 \%$ and $1.0 \%$ were tolerated, in the average dimensions and mass of each specimen, respectively. The compaction degree was always between 99 and $101 \%$ of the target value, while a maximum variation of $5 \%$ was admitted for the average moisture content. Specimens were cured in a humid room at a temperature of $23{ }^{\circ} \mathrm{C} \pm 2{ }^{\circ} \mathrm{C}$ and relative humidity of $90 \%$ [50]. Three specimens per result were fabricated, and curing periods of 7, 14, 28, 60 and 120 days were adopted. The mix proportions used can be seen in Table 3 .

Table 3. Mix proportion of the laboratory specimens.

\begin{tabular}{ccccccc}
\hline Specimens & $\begin{array}{c}\text { GWG } \\
\mathbf{( \% )}\end{array}$ & $\begin{array}{c}\text { CL } \\
\mathbf{( \% )}\end{array}$ & $\begin{array}{c}\omega \\
\mathbf{( \% )}\end{array}$ & Liquid Fase & $\begin{array}{c}\gamma_{\mathbf{d}} \\
\mathbf{( k N / \mathbf { m } ^ { 3 } )}\end{array}$ & $\begin{array}{c}\text { Curing Period } \\
\text { (Days) }\end{array}$ \\
\hline $\mathrm{B}_{\mathrm{SHS}}$ & 30 & 7 & 11 & $\begin{array}{c}\text { SHS (3 molal) } \\
\text { Water }\end{array}$ & 16.0 & $\begin{array}{c}7,14,28,60 \text { and } \\
120\end{array}$ \\
\hline
\end{tabular}




\subsection{Recovery of the Field Specimens}

For the field-testing program, a total of four circular ground waste glass (GWG)carbide lime (CL)-sand layers were assembled, each with $300 \mathrm{~mm}$ thickness $\left(\mathrm{H}_{\mathrm{r}}\right)$ and a diameter $\left(D_{\mathrm{r}}\right)$ of $450 \mathrm{~mm}$. Those dimensions were established according to the equipment available for its construction that would guarantee a good homogenization of the material and allow the removal of a number of cylindrical samples suitable for carrying out the determined analyzes.

The pits, with the specified dimensions, were manually dug into the soil surface. The molding of the field layers followed a similar procedure to that already used in the laboratory. However, in this case, the materials were prepared on a $450 \mathrm{~L}$ capacity mixer, while the compaction of each layer was performed manually. In order to control the specific weight and humidity, samples were taken from each compacted layer according to NBR 9813 [51], in which a cylinder with a cutting edge is seated on the ground surface, properly leveled and, through the free fall of a tamping socket, it is tamped into the material until its upper edge is $1.0 \mathrm{~cm}$ below the ground surface. Subsequently, with the help of spatulas, the soil is cut around the cylinder and below its lower edge. With a beveled ruler, the faces of the specimen are scraped. The mass of the cylinder containing the material is determined immediately in order to avoid loss of moisture. Thus, by knowing the mass and volume of the cylinder, the dry unit weight of the soil in situ is obtained. Table 4 summarizes the dry unit weight $\left(\gamma_{d}\right)$ and moisture content $(\omega)$ values obtained in the field during the molding process. These results were similar to the initial requirements of $\omega=11 \%$ and $\gamma_{d}=16.0 \mathrm{kN} / \mathrm{m}^{3}$, which indicates the homogeneity of the mixture and compaction efficiency. The field molding process can be followed from Figure 3.

Two layers, $\mathrm{B}_{\mathrm{SHS}}$ and $\mathrm{B}_{\mathrm{H} 2 \mathrm{O}}$, were allowed to cure for 14 days, while another two cured for 120 days. During the curing period, the climatic conditions of the place where the layers were made (Southern Brazil) were monitored (i.e., these data were retrieved from the local weather station, located close to the experimental field) in order to present the real conditions (temperature and precipitation) in which the layers of the field were submitted during the cure. After the curing period, the layers were extracted from the soil (Figure 4a), and cylindrical samples were manually removed from the layers and carefully trimmed to attain $50 \mathrm{~mm}$ in diameter and $100 \mathrm{~mm}$ in height (Figure $4 \mathrm{~b}$ ) to later be tested for unconfined compression.

\subsection{Specimen Testing}

The unconfined compressive strength tests (UCS) were carried out on an automatic press machine, under strain-controlled conditions (axial displacement of $1.14 \mathrm{~mm} / \mathrm{min}$ ), following the contents of the ASTM C39 [52]. Approximately $24 \mathrm{~h}$ before the test, the specimens were submerged in water to mitigate possible suction effects [53].

The initial shear modulus $\left(G_{0}\right)$ was determined through ultrasonic pulse velocity tests. The shear wave was measured on samples before UCS tests, considering that the ultrasonic pulse velocity test is non-destructive. An ultrasonic pulse device was utilized to measure the shear waves. A high viscosity gel was applied on the transducers, which were then attached to the extremities of the samples for the measurement of the waves. For a homogeneous and elastic medium, $G_{0}$ is the product of the bulk density by the square of the velocity of a shear wave passing through it [45].

Table 4. Values of dry unit weight and moisture content for each experimental layer, determined during the molding process.

\begin{tabular}{ccccc}
\hline \multirow{2}{*}{ Material } & \multicolumn{2}{c}{ Dry Unit Weight $\mathbf{( k N / \mathbf { m } ^ { \mathbf { 3 } } )}$} & \multicolumn{2}{c}{ Moisture Content (\%) } \\
\cline { 2 - 5 } & 14d Curing & 120d Curing & 14d Curing & 120d Curing \\
\hline $\mathrm{B}_{\mathrm{H} 2 \mathrm{O}}$ & 16.43 & 16.31 & 10.58 & 11.05 \\
$\mathrm{~B}_{\mathrm{SHS}}$ & 16.41 & 16.12 & 10.58 & 10.33 \\
\hline
\end{tabular}




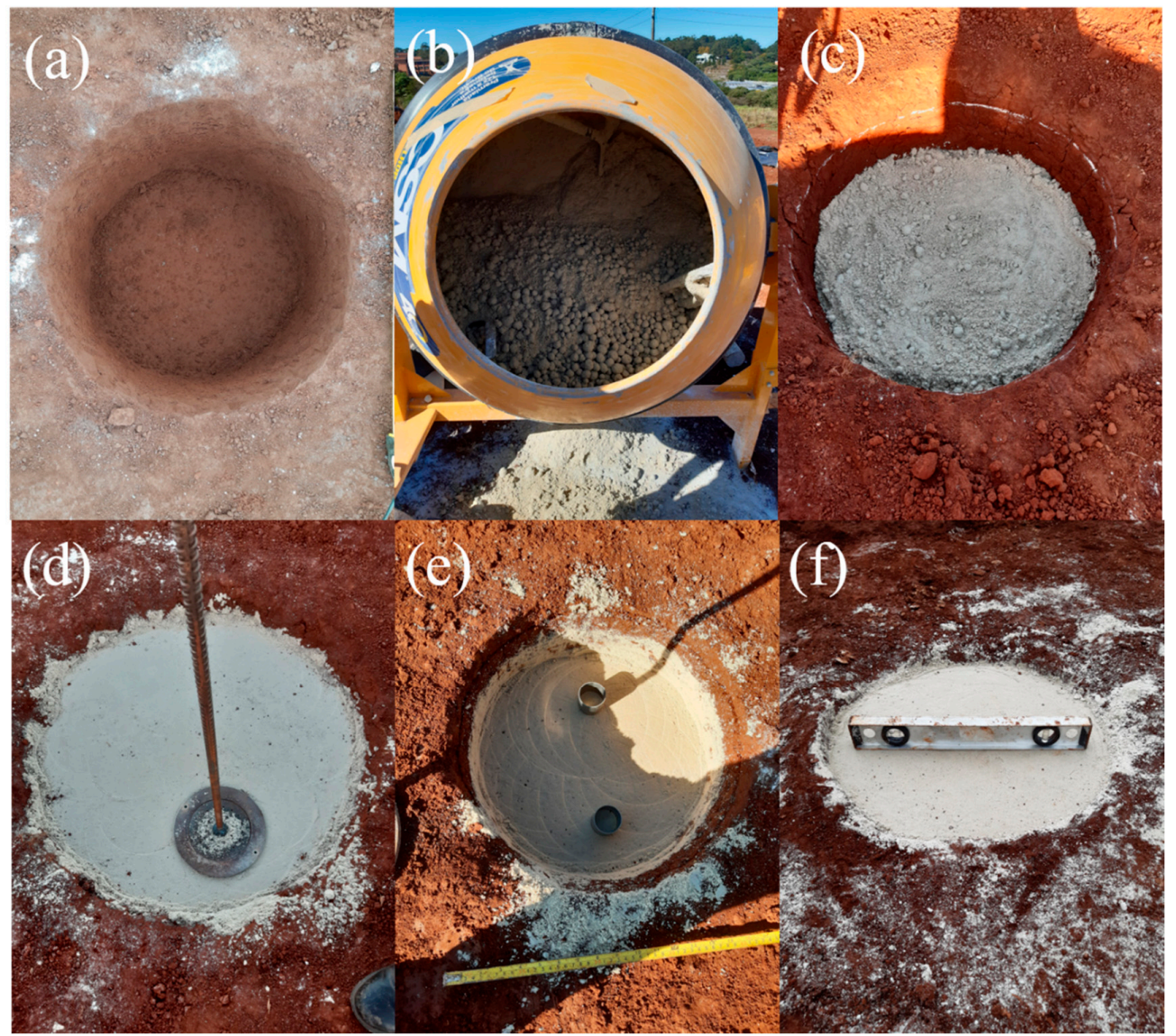

Figure 3. Field molding process (a) pit opening; (b) mixing preparation; (c) mixture placed in the pit; (d) compaction of the mixture; (e) sampling to control specific weight and humidity; (f) final stabilized layer.

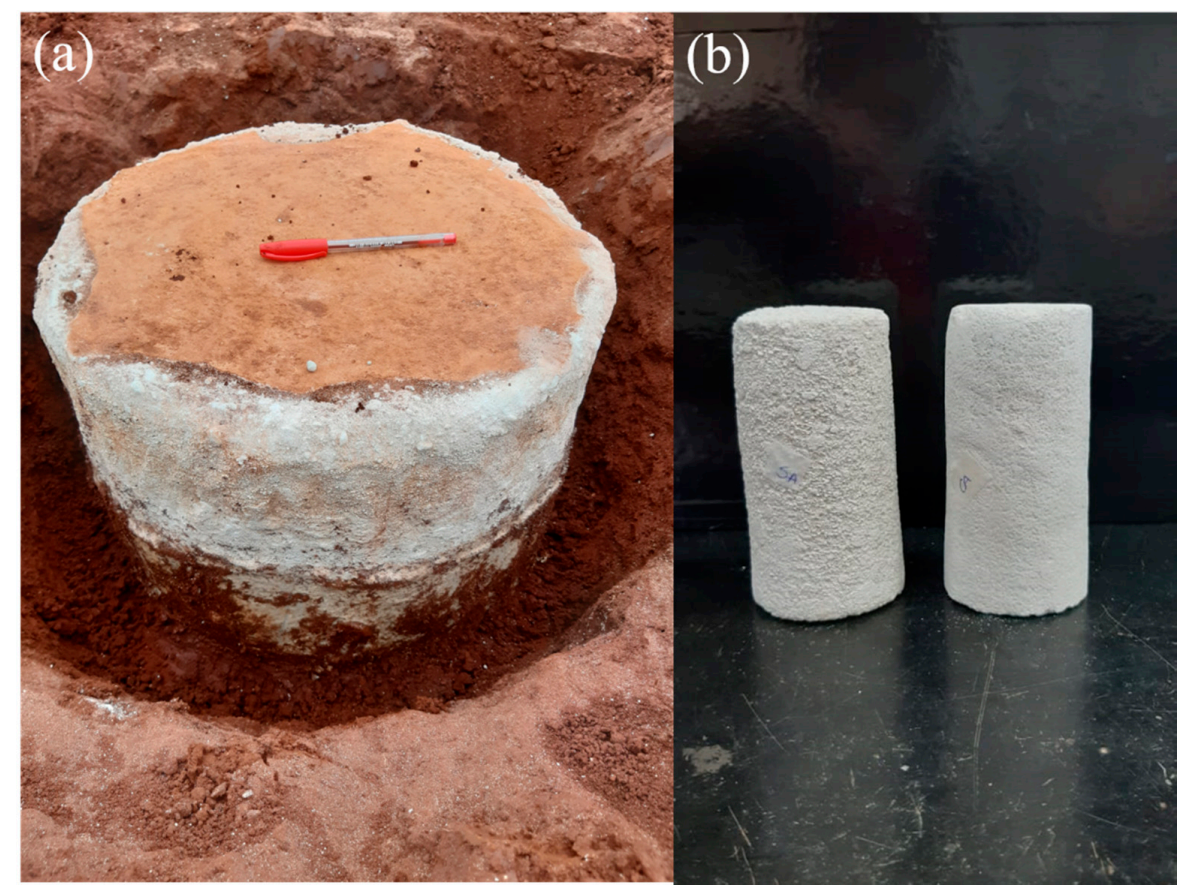

Figure 4. General procedure followed to retrieve samples for laboratory testing (a) starting with the side excavation of the field sample; (b) from which several cylindrical specimens were then collected with manual trimming. 


\subsection{Spread Footing Testing}

Seven circular layers stabilized either with $\mathrm{B}_{\mathrm{SHS}}$ or $\mathrm{B}_{\mathrm{H} 2 \mathrm{O}}$, with diameters $\left(\mathrm{D}_{\mathrm{r}}\right)$ of 450 and $900 \mathrm{~mm}$ and thick $\left(\mathrm{H}_{\mathrm{r}}\right)$ of $300 \mathrm{~mm}$ (Figure 5), were fabricated on a slightly cemented residual soil, fully characterized by [11] and [54]. Eight layers were initially planned, but one was damaged during fabrication. These layers were then submitted to Plate Load Tests (PLT) by using a circular $300 \mathrm{~mm}$ rigid plate. The dimensions of the layers were chosen based on previous work $[11,37,55]$. Figure 6 shows the relative distribution of the stabilized layers in the field. The distances between layers were defined considering the required minimum spacing between the edges of adjacent layers, which, as recommended by [10], was set at twice the diameter of the largest layer. The tests were carried out after curing periods of 14 and 120 days.
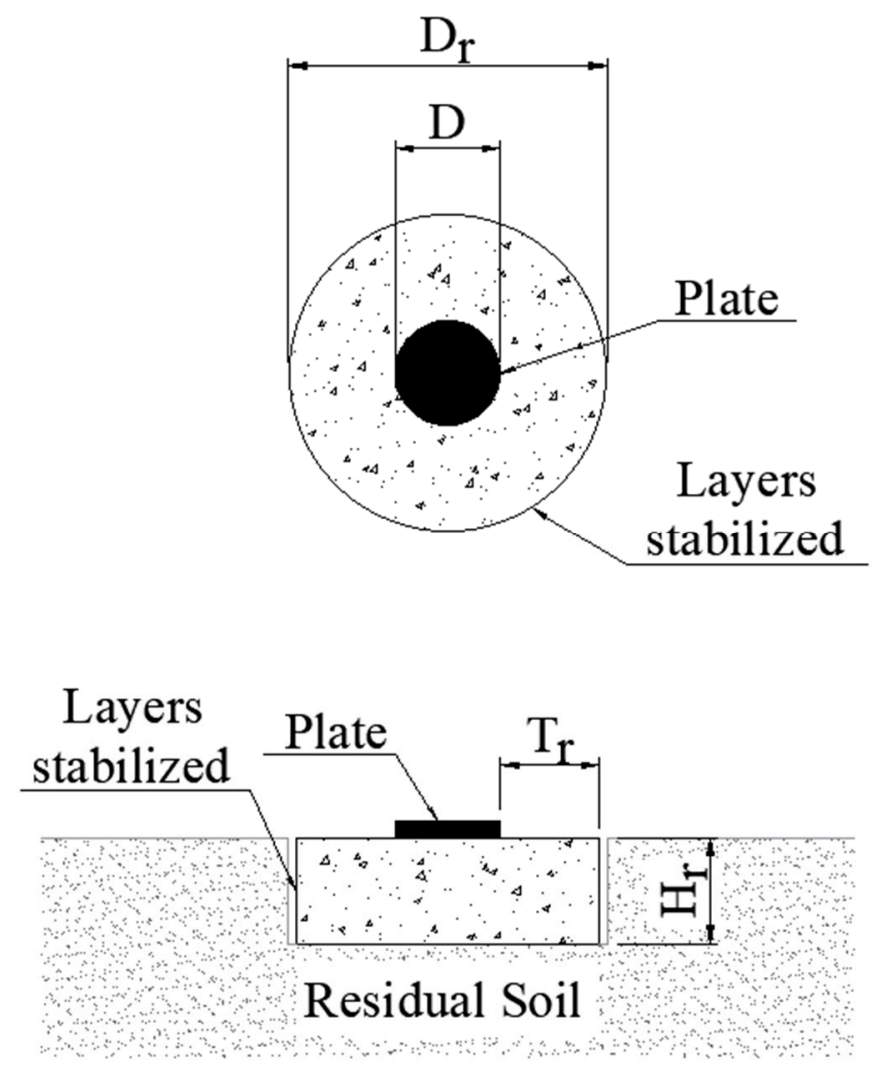

Figure 5. Geometry of the stabilized layers and Load Plate Test setup.

The PLT procedure followed the recommendations of [56]. The load $(Q)$ was applied using a hydraulic jack installed under a loaded reaction structure (Figure 7a,b). The readings were performed with a load cell, properly calibrated in the laboratory, and a data acquisition system. The measurement of the vertical displacement was performed using resistive rulers with a course of $50 \mathrm{~mm}$ and a resolution of $0.01 \mathrm{~mm}$, positioned at three different points on top of the plate (Figure 7c). The load increments applied in each stage were previously defined as $10 \%$ of the expected rupture load. For the definition of the load capacity, the criterion of [18] was used, where the breaking load $\left(Q_{u}\right)$ is defined as the point on the stress-settlement curve corresponding to a relative settlement $(\delta / D)$ of $3 \%$. 


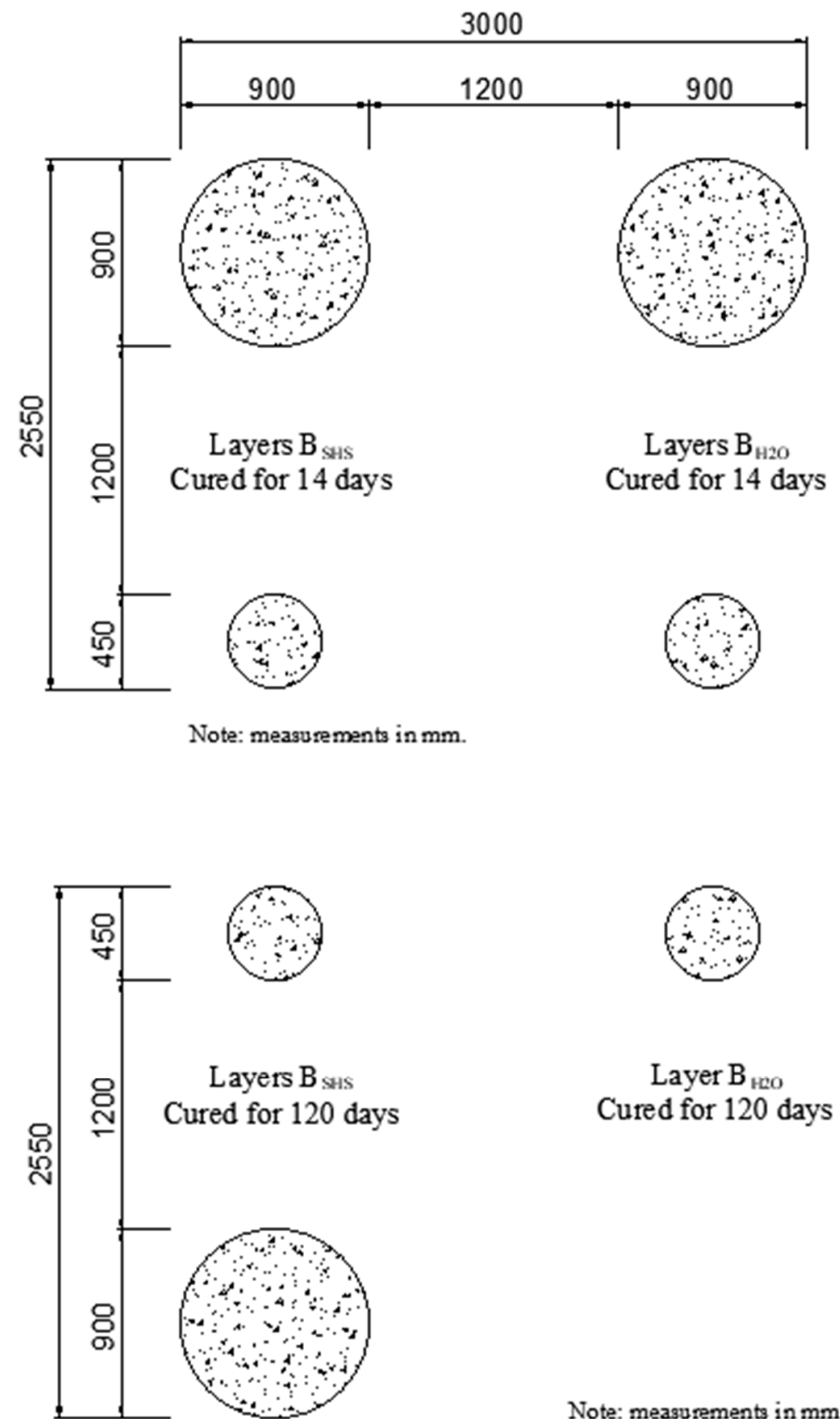

Figure 6. Relative distribution of the stabilized layers in the field. 


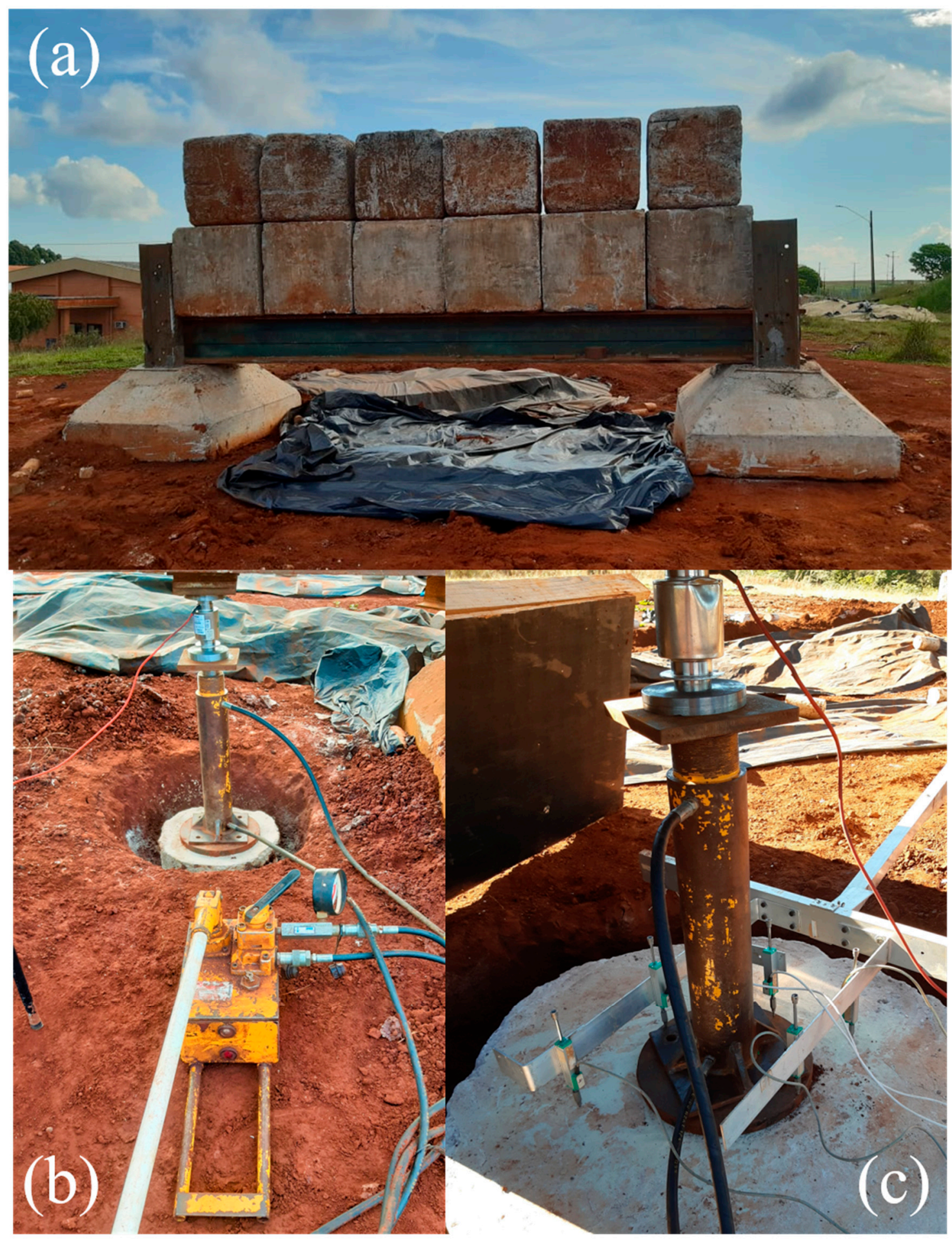

Figure 7. Load application system (a) reaction structure; (b) load application; (c) measurement of the vertical displacement.

\section{Results and Discussion}

3.1. Evolution of UCS with Time

The results obtained during the unconfined compressive strength tests (UCS) are shown in Figure 8. The results for mixtures with SHS varied from $400 \mathrm{kPa}$ to $5000 \mathrm{kPa}$ and 155 to $5000 \mathrm{kPa}$ without SHS. These values are the average of three tests, with each individual strength value not deviating more than $\pm 10 \%$ from the average. A strength increase with curing time can be observed, up until day 120 . This behavior is related to the 
pozzolanic capacity of the waste glass, which reacts with the calcium hydroxide $\left[\mathrm{Ca}(\mathrm{OH})_{2}\right]$ available in the $\mathrm{CL}$, forming a bonding matrix. These pozzolanic reactions are known to develop for periods well beyond the 28-days period usually considered for the assessment of OPC-based binders. Moreover, relevant is the higher short-term strength produced by the alkali-activated material compared with the material hydrated with water. Since the pozzolanic reactions depend on the development of a strongly alkaline environment, the presence of the activator creates such an environment immediately after the materials are mixed. On the contrary, the $\mathrm{CL}$ is less effective at increasing the $\mathrm{pH}$ of the mixture, resulting in lower dissolution rates of the silica (from the glass). After 120 days, the differences are practically null, as the hydrated material had time to develop similar volumes of binding gel.

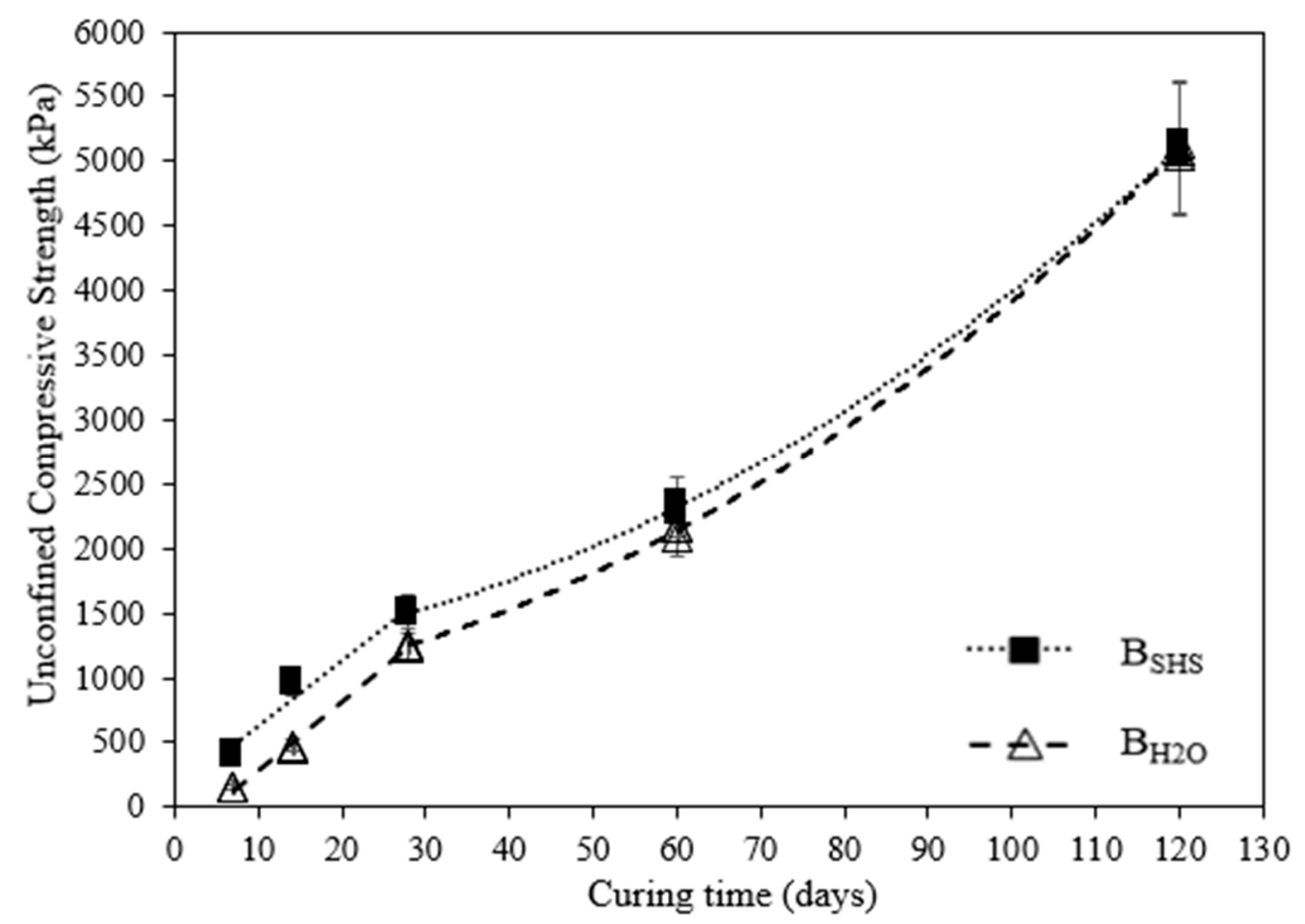

Figure 8. Variation in the UCS of the laboratory specimens with curing time.

UCS ratio between the stabilized and natural specimens, which initially was approximately 2.6 (i.e., more than double), decreased to 1 after the longest curing period considered. According [28], the biggest difference between the pozzolanic reactions and alkaline activation is that the alkaline metal $(\mathrm{NaOH})$ is more effective than the alkaline earth metals (calcium) due to the higher initial $\mathrm{pH}$ that the activating solution provides, thus dissolving and breaking the original structure more effectively.

\subsection{Field and Laboratory Results Comparison}

The samples extracted from the field layers were also submitted to UCS testing. Figure 9 shows the UCS of the samples recovered from the field after 14 and 120 days and compares these values with those obtained in the laboratory. The field results for mixtures with SHS varied from 850 to $1730 \mathrm{kPa}$ and 220 to 940 without SHS. As is usually the case, the field results are lower than those obtained with the specimens fabricated in the controlled environment of the laboratory. Such difference is more significant after 120 days since the material spent more time exposed to the environment and, thus, was less capable of developing higher UCS levels (when compared with those obtained in the laboratory). 


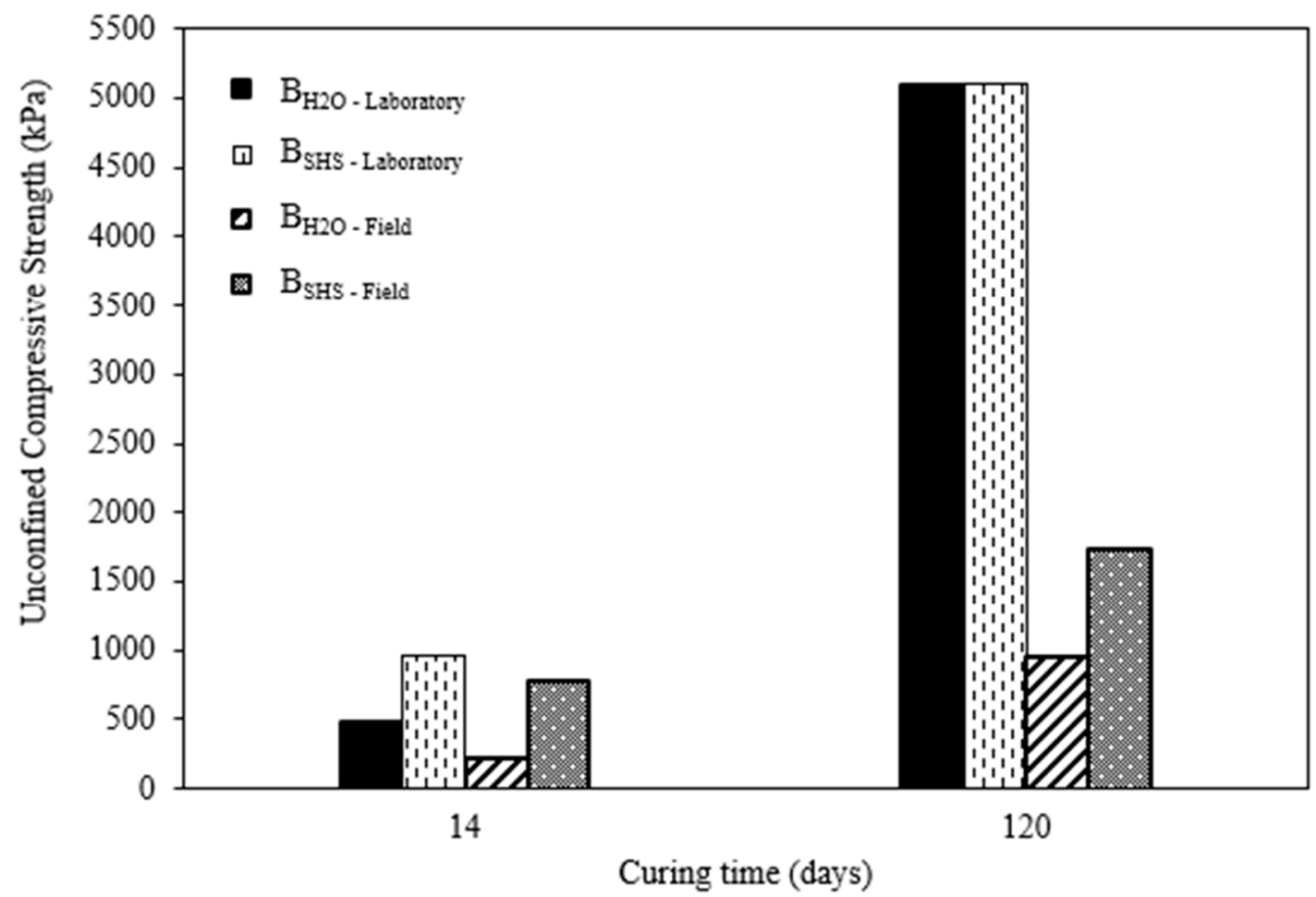

Figure 9. UCS for field and laboratory samples for curing time of 14 and 120 days.

After 14 days of curing, the field/laboratory ratio was 0.80 for the $\mathrm{B}_{\mathrm{SHS}}$ material and 0.49 for the $\mathrm{B}_{\mathrm{H} 2 \mathrm{O}}$ material. After 120 days, the same ratio decreased to 0.35 (B $\mathrm{B}_{\mathrm{SHS}}$ ) and $0.18\left(\mathrm{~B}_{\mathrm{H} 2 \mathrm{O}}\right)$, suggesting that the curing conditions (i.e., relative humidity, temperature and precipitation) assumed an important role regarding the production and development of the cementitious gel. In addition to the curing conditions, an important factor to be considered for the UCS results is the difference of the molding process from field to laboratory because, in the laboratory, there is greater control and precision over the molding conditions, such as mixture homogeneity, degree of compaction and guarantee of the shape and measures of the specimen (i.e., vertical sides and flat surfaces), which consequently give better strength results. Moreover, the extraction of the specimens taken from the field sample may have interfered in the results of UCS of the samples recovered the field because, as they were sculpted by hand, the sides and loading surfaces of the specimens were not precisely regular (Figure $4 \mathrm{~b}$ ), which certainly interfered in the strength, negatively. It should also be noticed that the lowest ratios for each curing period were obtained BSHS, which can be interpreted as an indication of higher durability of the alkaline-activated material.

Figure 10 shows the monitoring of the climatic conditions to which the stabilized layers were exposed during the curing period. The average temperature was around $15^{\circ} \mathrm{C}$, therefore lower than the laboratory environment, which most likely hindered the field results. According to the data collected from the weather station, precipitation of approximately $100 \mathrm{~mm}$ was registered in the first 14 days of curing, with an increase to $230 \mathrm{~mm}$ in the third week. Such high precipitation during the initial and crucial stage of the reactions may have reduced the $\mathrm{pH}$ of the pastes and, thus, conditioned the strength development. These climatic conditions, characteristic of the Southern region of Brazil, can significantly influence the field performance, especially of the layers without alkaline activator, which usually show slower development rates than the activated systems.

Figure 11 shows the variation in the initial shear modulus $\left(G_{0}\right)$ (average value of three specimens) for the same specimens submitted to the UCS tests. In every case, the $\mathrm{G}_{0}$ increases with increasing curing time. However, the laboratory $\mathrm{B}_{\mathrm{SHS}} / \mathrm{B}_{\mathrm{H} 2 \mathrm{O}}$ ratios for samples cured for 14 and 120 days were 2.85 and 2.34, respectively. This difference was even higher for the field-cured material, with ratios of 3.85 and 4.31 after curing periods of 
14 and 120 days, respectively. As expected after the analysis of the UCS results, the field samples showed lower stiffness than the laboratory samples, with lab/field ratios of 2.58 $(14 \mathrm{~d})$ and $2.39(120 \mathrm{~d})$ for the $\mathrm{B}_{\mathrm{H} 2 \mathrm{O}}$ material, and $1.70(14 \mathrm{~d})$ and $1.44(120 \mathrm{~d})$ for the $\mathrm{B}_{\mathrm{SHS}}$ material.

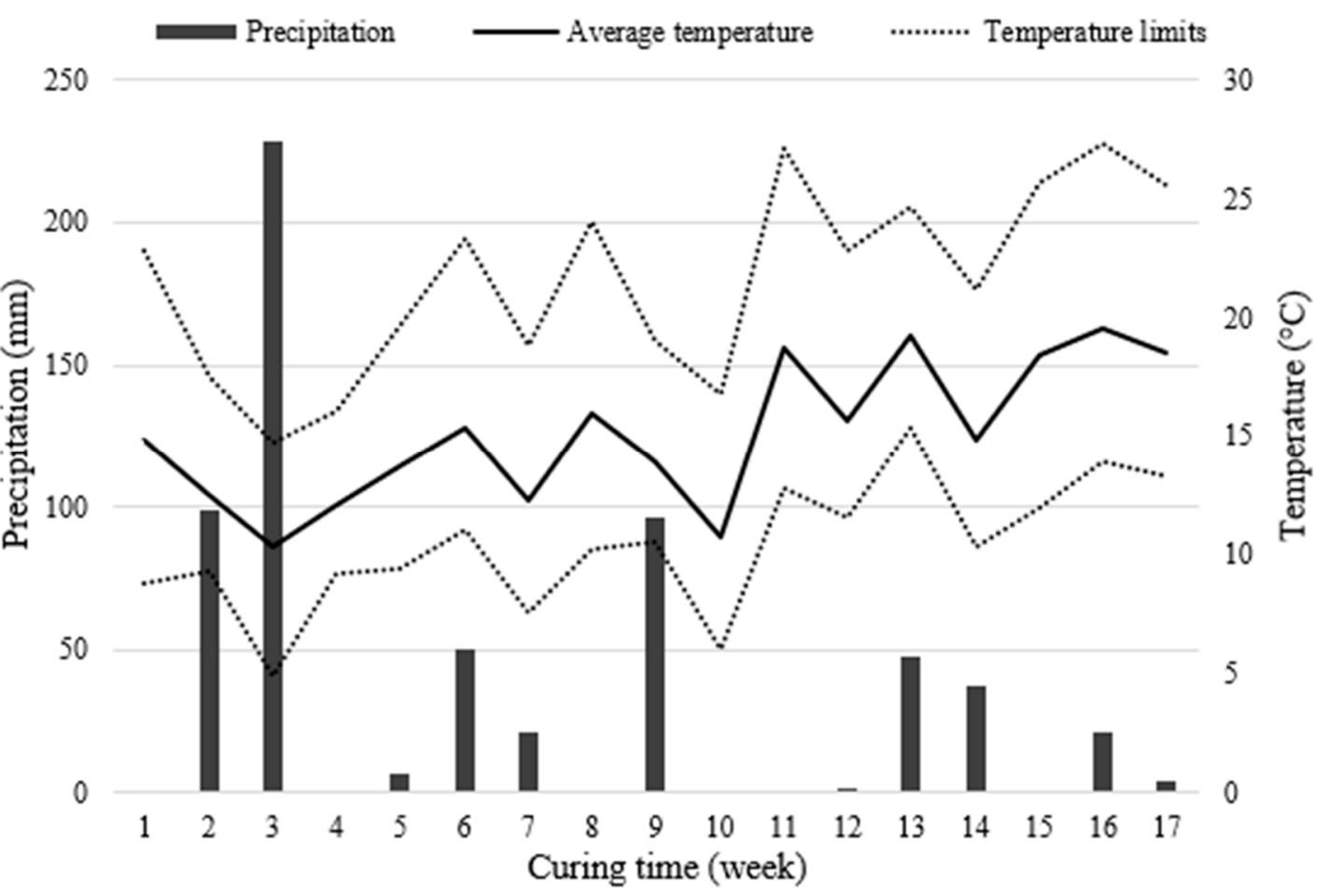

Figure 10. Precipitation and temperature during the curing period.

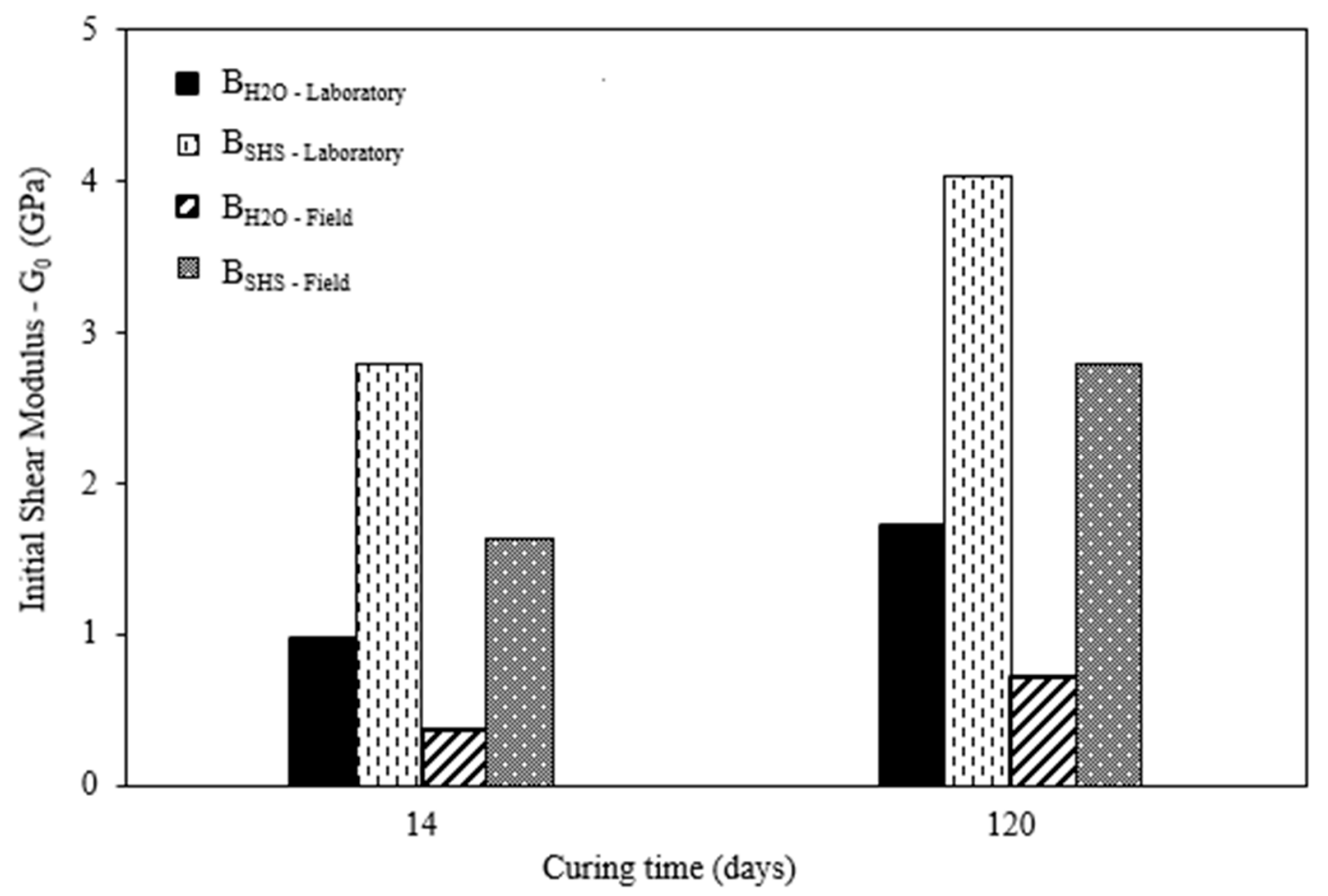

Figure 11. Initial shear modulus for field and laboratory samples for curing time of 14 and 120 days. 


\subsection{Spread Footing Testing}

Figure 12 shows the load vs. settlement results of the plate tests performed on the seven field layers. The loading capacity of the natural soil, which was used as a reference in the present study, was determined by [11]. The stabilization produced an initial strength increase relative to the response of the natural soil.
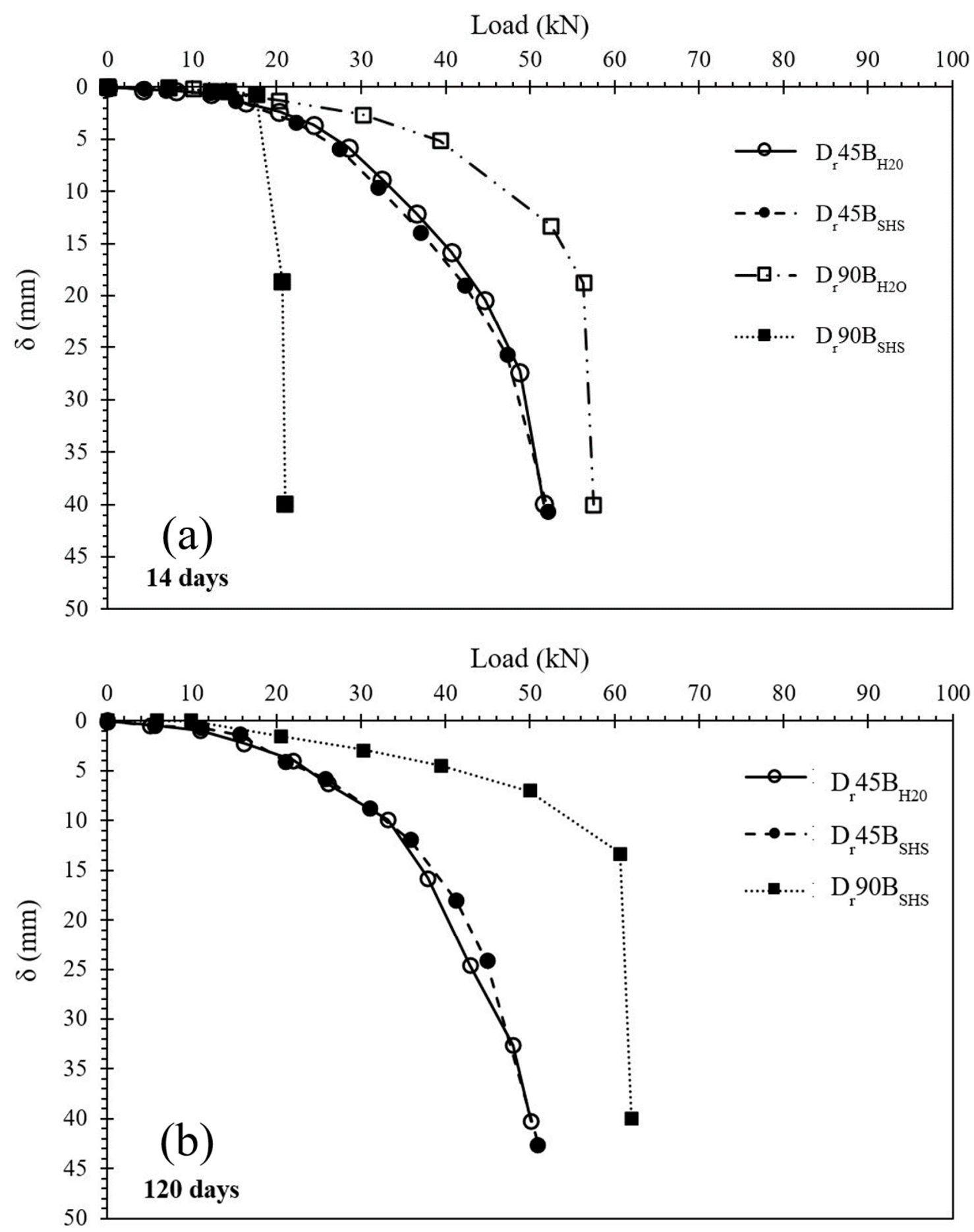

Figure 12. Load vs. settlement (a) Cured for 14 days; (b) Cured for 120 days.

For better observation of the general trends verified in the two diameters used, the applied loads and the respective settlements were normalized by the area, and the resulting stress was then plotted as a function of the relative settlement $(\delta / D r)$. Figure 13 shows that, 
after normalization, most curves are approximately superimposed, including that from the natural soil. The representation of the normalized results thus suggests that, regarding the $D_{r} 450 \mathrm{~mm}$ tests, failure was controlled by the load capacity of the soil underlying the stabilized layer. As the load increases, there is a progressive breaking of the bonds of the weakly cemented residual soil supporting the stabilized layers, resulting in the vertical penetration of the foundation with practically no lateral movement of the soil. This behavior is typically observed when structured soils lose their fabric [54]. The $\mathrm{D}_{\mathrm{r}}$ $900 \mathrm{~mm}$ layers reached the failure before the load capacity of the natural soil was exceeded (note that this capacity is higher than that of the foundation soil of the $D_{r} 450 \mathrm{~mm}$ layers), which justifies that the overlapping of the normalized $900 \mathrm{~mm}$ curves with the normalized $450 \mathrm{~mm}$ curves occurs only for an initial relative deformation of approximately $0.1 \%$.

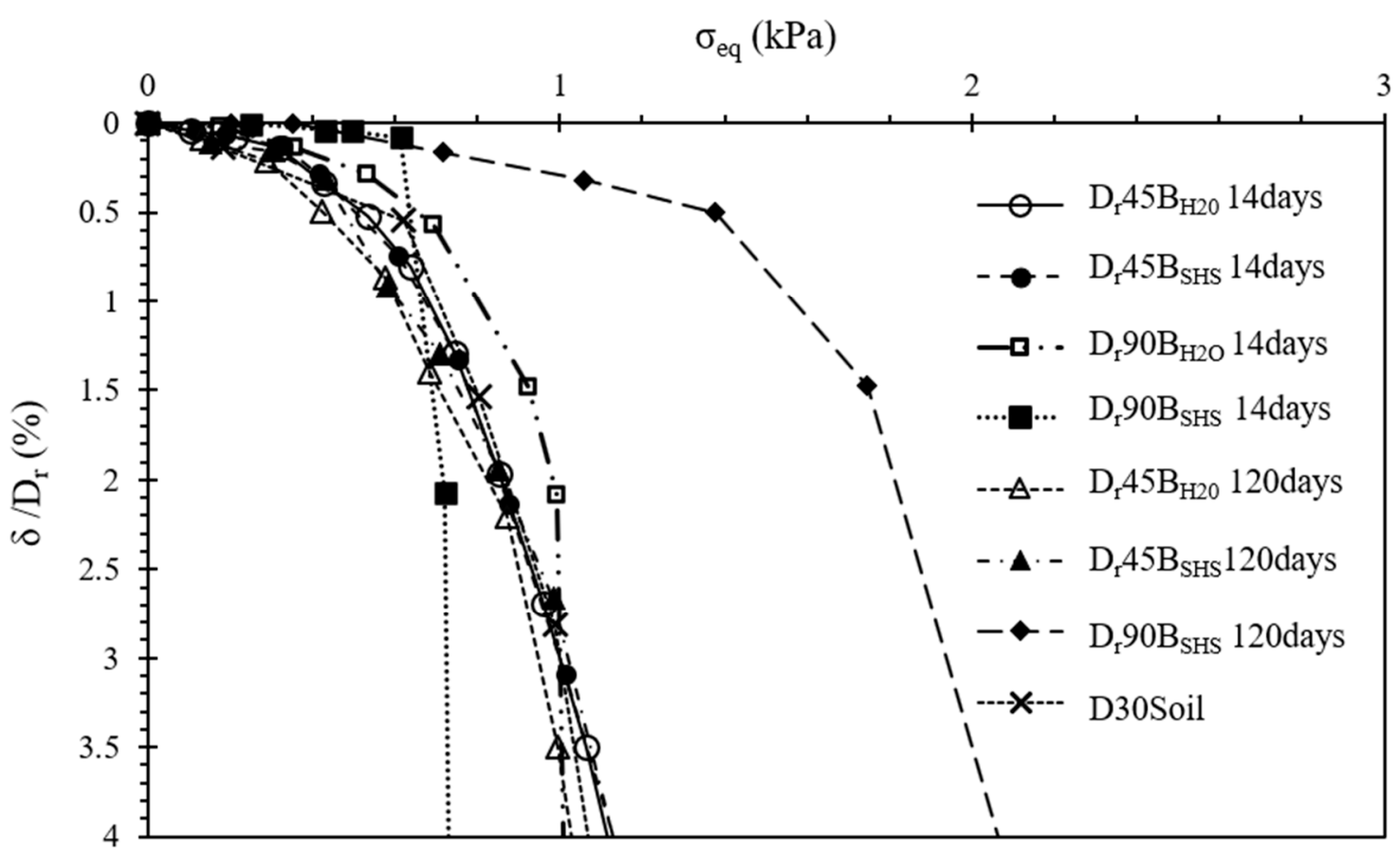

Figure 13. Normalization of results.

In general, there was a proportionality between the load capacity and the reinforced diameter-for the same load, lower displacements were observed for the higher diameter. However, the failure mechanism was different for each diameter. For the smaller diameter $\left(\mathrm{D}_{\mathrm{r}} 450 \mathrm{~B}_{\mathrm{SHS}}\right.$ and $\mathrm{D}_{\mathrm{r}} 450 \mathrm{~B}_{\mathrm{H} 2 \mathrm{O}}$ ), a puncture failure mechanism occurred when the steel plate and the stabilized layer underneath behaved as a single element and penetrated the soil without any lateral movement. This mechanism was fully observed during the analysis of the exhumed layers when it became clear the soil penetration without any visible cracks (Figure 14). 


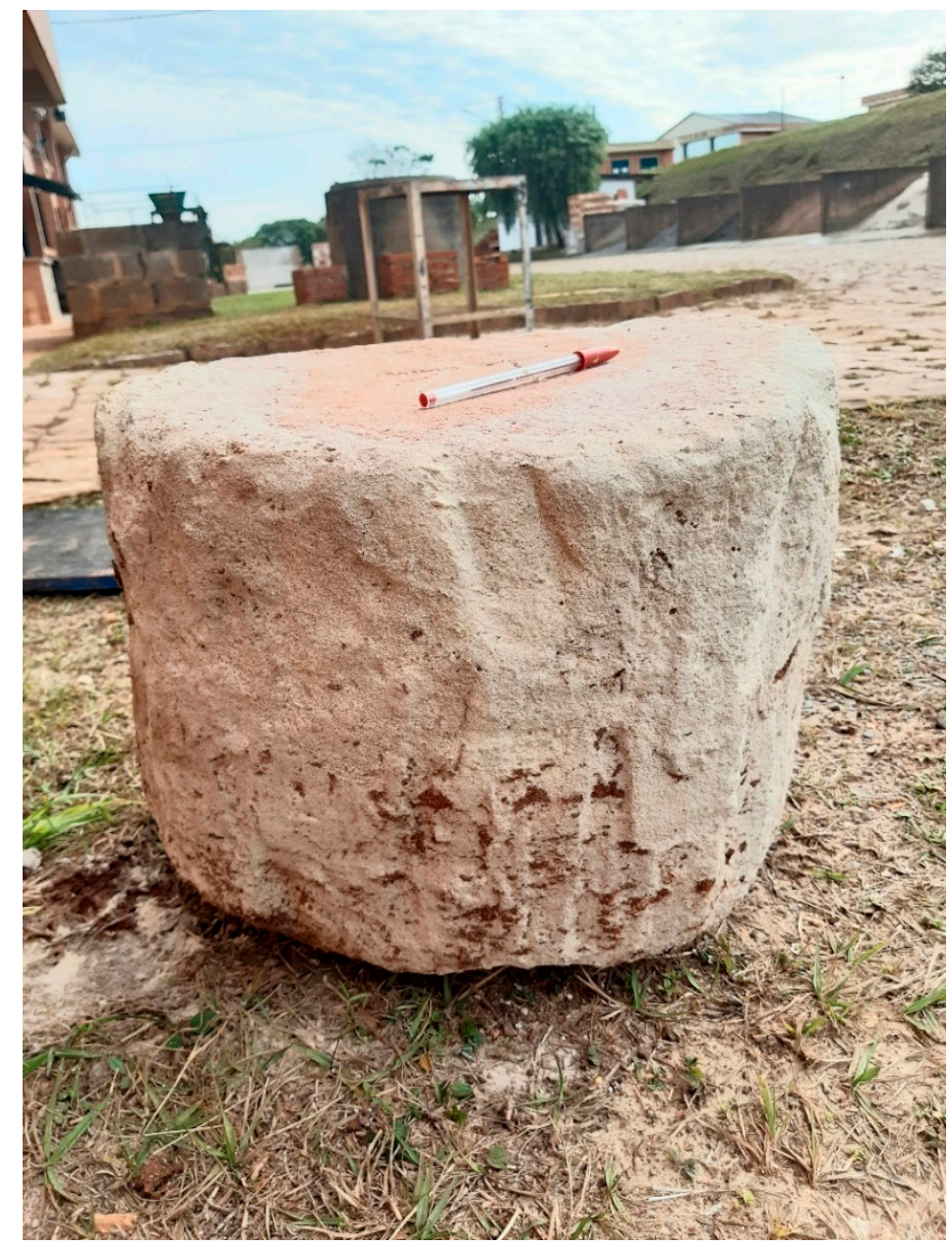

Figure 14. $D_{\mathrm{r}} 450 \mathrm{~mm} \mathrm{~B}_{\mathrm{SHS}}$ stabilized layer exhumed from the soil.

The larger diameters $\left(\mathrm{D}_{\mathrm{r}} 900 \mathrm{~B}_{\mathrm{SHS}}\right.$ and $\left.\mathrm{D}_{\mathrm{r}} 900 \mathrm{~B}_{\mathrm{H} 2 \mathrm{O}}\right)$ showed a different failure mode, characterized by punching shear, which resulted in the clear separation of a cylinder located beneath the circular plate from the remaining body of the stabilized layers (Figure 15). Some tension cracks were also formed inside the cylinder when it tried to expand laterally due to the Poisson's effect. Additionally, two or three radial cracks developed from the center to the edges. Similar failure modes and cracking patterns were found by [11,24], soil stabilized with Portland cement. 

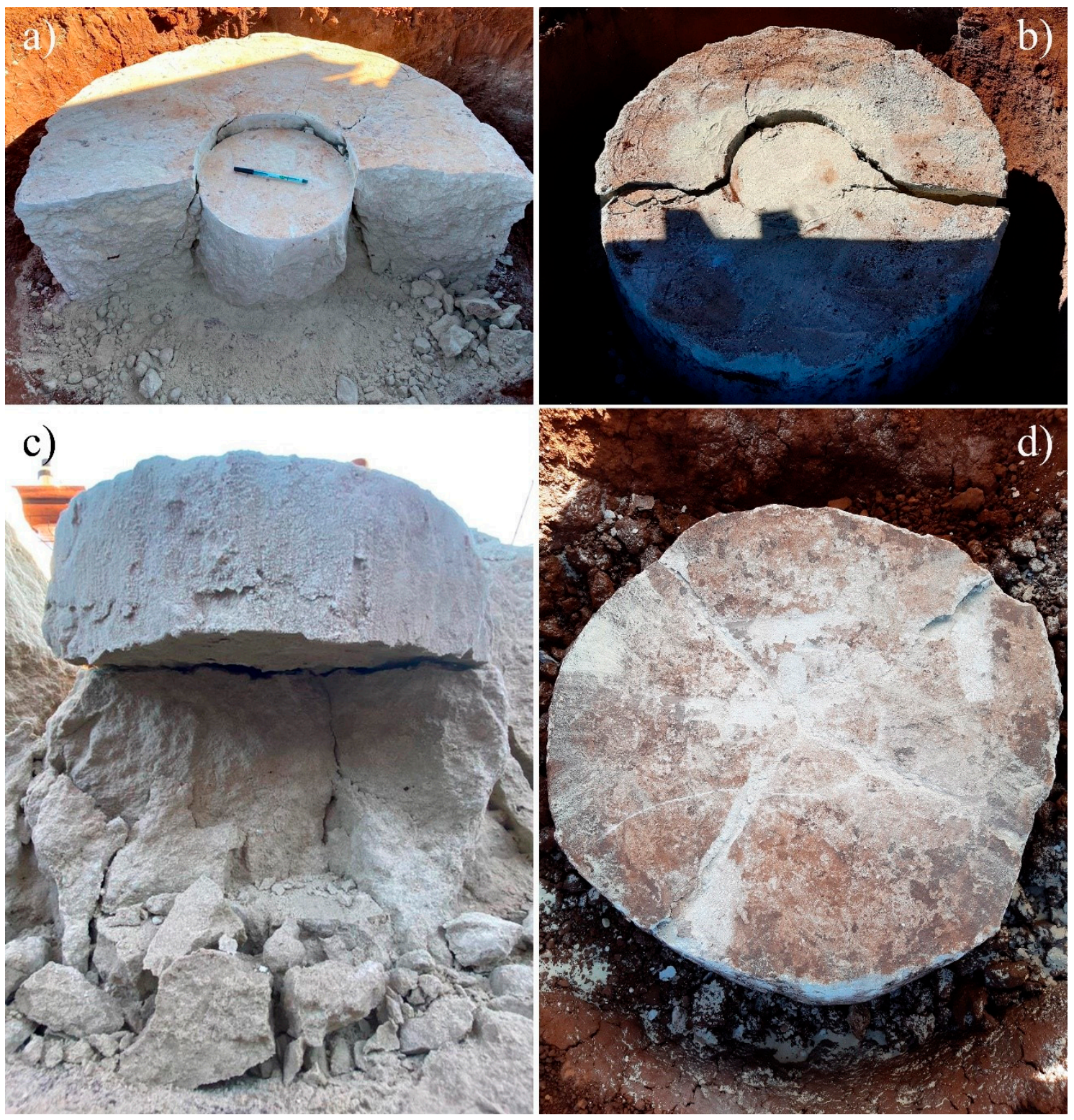

Figure 15. $\mathrm{D}_{\mathrm{r}} 900 \mathrm{~mm} \mathrm{~B} \mathrm{BHS}_{\mathrm{SHS}}$ and $\mathrm{B}_{\mathrm{H} 2 \mathrm{O}}$ stabilized layers exhumed from the soil; (a) cutting the layers to identify cracks; (b) identification of external cracks; (c) cracks in the center of the layer underneath the foundation; (d) cracks in the top layer.

\section{Conclusions}

The present work assessed the application of alkali-activated cement based on industrial wastes to stabilize the residual layer supporting a superficial load. From the results obtained, it was possible to draw the following conclusions:

(a) Regarding the laboratory mixtures, the material activated with a $3 \mathrm{M}$ sodium hydroxide solution presented a higher compressive strength (UCS) than the material hydrated with water, but only for short-term curing periods. The alkalinity of the activator enhances the initial dissolution of the original silica, resulting in a strength $2.6 \times$ higher than the water-based mixtures. With the increase in curing time, the latter was able to develop similar volumes of binder, thus obtaining similar UCS values. In the present research, the results for $\mathrm{NaOH}$ mixtures varied from $0.4 \mathrm{MPa}$ to $5.0 \mathrm{MPa}$ for laboratory tests and $0.2 \mathrm{MPa}$ to $1.7 \mathrm{MPa}$ for field results, depending on the curing period. Therefore, some of the results are contained in the minimum values required by soil-cement standards and can also be considered for projects with lower stresses; 
(b) Comparing the field and laboratory UCS data, it is clear that the former showed lower strength for both types of the mixture, which is attributed to the influence of the climatic conditions during curing, which was controlled in the laboratory, and to a molding precision of the specimens made in the laboratory with greater control regarding mixtures homogeneity, degree of compaction and control of shape and measurements (i.e., vertical sides and flat surfaces). As the curing period increased, the difference between field and laboratory became more significant, which was aggravated by the higher precipitation registered in the region during the last 7 weeks of the curing period, compared with the first 10 weeks;

(c) The stiffness $\left(G_{0}\right)$ results obtained in the field were lower than those obtained in the laboratory for both types of mixture. With the increase in curing time, there was an increase in stiffness. However, the AAC-based mixtures showed higher initial stiffness values than the water-based mixtures in the laboratory and in the field. This was contrary to what was observed with the UCS, after 120 days, when the hydrated material showed higher compressive strength than the activated material;

(d) The plate load tests showed that the stabilization of the surface layer significantly increased the load-bearing capacity compared with the natural soil. An increase in the diameter of the stabilized layer also provided a higher load-bearing capacity. Two different failure mechanisms were observed, depending on the dimensions of the reinforcement layers, with the $450 \mathrm{~mm}$ layer showing a puncture mechanism, while the $900 \mathrm{~mm}$ layer showed the appearance of cracks;

(e) Data normalization suggests that, in the case of the $450 \mathrm{~mm}$ layers, the foundation (plate) and the stabilized layer behaved as a single element, supported on the lower stabilized base, meaning that the failure load is controlled by the capacity of the soil beneath it. For the $900 \mathrm{~mm}$ diameter, the failure occurred when the applied load exceeded its tensile stress.

Author Contributions: Methodology, N.C.C.; investigation, M.P.S. and D.T.M.; resources, N.C.C. and M.F.F.; data curation, M.P.S. and D.T.M.; writing—original draft preparation, M.P.S.; writing—review and editing, D.T.M., N.C. and T.M.; supervision, N.C.C.; project administration, N.C.C.; funding acquisition, N.C.C. All authors have read and agreed to the published version of the manuscript.

Funding: This research received no external funding.

Institutional Review Board Statement: Not applicable.

Informed Consent Statement: Not applicable.

Acknowledgments: The authors wish to explicit their appreciation to FAPERGS/CNPq 12/2014PRONEX (Project \# 16/2551-0000469-2), MCT-CNPq (Editais INCT-REAGEO, Universal and Produtividade em Pesquisa) and MEC-CAPES (PROEX) for the support to the research group.

Conflicts of Interest: The authors declare no conflict of interest.

\section{References}

1. Abdeldjouad, L.; Asadi, A.; Ball, R.; Nahazanan, H.; Huat, B.B. Application of alkali-activated palm oil fuel ash reinforced with glass fibers in soil stabilization. Soils Found. 2019, 59, 1552-1561. [CrossRef]

2. ABNT NBR 9813. Solo-Determinação da Massa Específica Aparente In Situ, Com Emprego de Cilindro de Cravação. Available online: http:/ / files.ilcoribeiro.webnode.com.br/200000080-6bf7f6cf24/NBR\%209813.pdf (accessed on 13 March 2021).

3. ABNT NBR 12253. Solo-Cimento-Dosagem Para Emprego Como Camada de Pacimento. Available online: https: / / www.target.com.br/produtos/normas-tecnicas/36229/nbr12253-solo-cimento-dosagem-para-emprego-como-camada-depavimento-procedimento (accessed on 13 March 2021).

4. Alonso, S.; Palomo, A. Alkaline activation of metakaolin and calcium hydroxide mixtures: Influence of temperature, activator concentration and solids ratio. Mater. Lett. 2001, 47, 55-62. [CrossRef]

5. ASTM. ASTM D7928. Standard Test Method for Particle-Size Distribution (Gradation) of Fine-Grained Soils Using the Sedi-Mentation (Hydrometer) Analysis; ASTM: West Conshohocken, FL, USA, 2021.

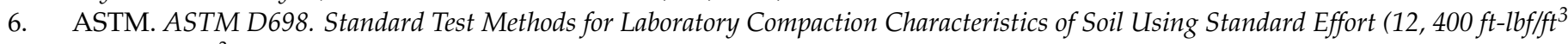
$\left.\left(600 \mathrm{kN}-\mathrm{m} / \mathrm{m}^{3}\right)\right)$; ASTM: West Conshohocken, FL, USA, 2021. 
7. ASTM. ASTM C39/C39M. Standard Test Method for Compressive Strength of Cylindrical Concrete Specimens; ASTM: West Conshohocken, FL, USA, 2021.

8. ASTM. ASTM C511. Standard Specification for Mixing Rooms, Moist Cabinets, Moist Rooms, and Water Storage Tanks Used in the Testing of Hydraulic Cements and Concretes; ASTM: West Conshohocken, FL, USA, 2019.

9. ASTM. ASTM D2487. Standard Practice for Classification of Soils for Engineering Purposes (Unified Soil Classification System); ASTM: West Conshohocken, FL, USA, 2017.

10. ASTM. ASTM D1194. Standard Test Method for Bearing Capacity of Soil for Static Load and Spread Footings; ASTM: West Conshohocken, FL, USA, 1994.

11. Baldovino, J.J.; Izzo, R.L.; Rose, J.L.; Domingos, M.D. Strength, durability, and microstructure of geopolymers based on recycledglass powder waste and dolomitic lime for soil stabilization. Constr. Build. Mater. 2021, 271, 121874. [CrossRef]

12. Bicca Neto, V. Commitment Business for Recycling—Review; Coca Cola Company: Brasilia, Brazil, 2015; Available online: https: / / cempre.org.br/wp-content/uploads/2020/11/CEMPRE-Review2015.pdf (accessed on 20 March 2021).

13. Bruschi, G.J.; dos Santos, C.P.; de Araújo, M.T.; Ferrazzo, S.T.; Marques, S.F.V.; Consoli, N.C. Green Stabilization of Bauxite Tailings: Mechanical Study on Alkali-Activated Materials. J. Mater. Civ. Eng. 2021, 33, 06021007. [CrossRef]

14. Bruschi, G.J.; dos Santos, C.P.; Ferrazzo, S.T.; de Araújo, M.T.; Consoli, N.C. Parameters controlling loss of mass and stiffness degradation of 'green' stabilised tailings. Proc. Inst. Civ. Eng. Geotech. Eng. 2021, 164, 00119. [CrossRef]

15. Caballero, R.D. Development of a Design Methodology for Circular Surface Foundations Laid on a Soil-Cement Layer; Federal University of Rio Grande do Sul: Porto Alegre, Spain, 2019.

16. Carretta, M.D.S.; Cristelo, N.; Festugato, L.; Miguel, G.D.; Consoli, N.C. Experimental assessment of the small-strain response of residual soil under monotonic and cyclic loading. Proc. Inst. Civ. Eng. Geotech. Eng. 2021, 00073. [CrossRef]

17. Consoli, N.C.; Carretta, M.D.S.; Leon, H.B.; Filho, H.C.S.; Tomasi, L.F. Strength and Stiffness of Ground Waste Glass-Carbide Lime Blends. J. Mater. Civ. Eng. 2019, 31, 06019010. [CrossRef]

18. Consoli, N.C.; Casagrande, M.D.T.; Thomé, A.; Rosa, F.D.; Fahey, M. Effect of relative density on plate loading tests on fibrereinforced sand. Géotechnique 2009, 59, 471-476. [CrossRef]

19. Consoli, N.C.; Daassi-Gli, C.A.P.; Ruver, C.A.; Lotero, A.; Filho, H.C.S.; Moncaleano, C.J.; Lourenço, D.E. Lime-Ground GlassSodium Hydroxide as an Enhanced Sustainable Binder Stabilizing Silica Sand. J. Geotech. Geoenviron. Eng. 2021, 147, 06021011. [CrossRef]

20. Consoli, N.C.; Moreira, E.B.; Festugato, L.; Caballero, R.D.; Foppa, D.; Ruver, C.A. Enhancing bearing capacity of shallow foundations through cement-stabilised sand layer over weakly bonded residual soil. Géotechnique 2021, 064. [CrossRef]

21. Consoli, N.C.; Moreira, E.B.; Festugato, L.; Lopes, L.D.S.; Carretta, M.D.S.; Ceolin, A.O. Spread Footings on Green Stabilized Sand Layers over Weakly Bonded Residual Soil. J. Geotech. Geoenviron. Eng. 2020, 146, 06020022. [CrossRef]

22. Consoli, N.C.; Rosa, A.D.; Saldanha, R.B. Variables Governing Strength of Compacted Soil-Fly Ash-Lime Mixtures. J. Mater. Civ. Eng. 2011, 23, 432-440. [CrossRef]

23. Consoli, N.C.; Rosa, F.D.; Fonini, A. Plate Load Tests on Cemented Soil Layers Overlaying Weaker Soil. J. Geotech. Geoenviron. Eng. 2009, 135, 1846-1856. [CrossRef]

24. Consoli, N.C.; Rossi, J.G.; Festugato, L.; Ruver, C.A.; Filho, H.C.S.; Foppa, D.; Carretta, M.D.S.; Leon, H.B. Circular-Plate Load Tests on Bounded Cemented Layers above Weak Cohesive-Frictional Soil. J. Geotech. Geoenviron. Eng. 2019, 145, 06019011. [CrossRef]

25. Consoli, N.C.; Vendruscolo, M.A.; Prietto, P.D.M. Behavior of Plate Load Tests on Soil Layers Improved with Cement and Fiber. J. Geotech. Geoenviron. Eng. 2003, 129, 96-101. [CrossRef]

26. Consoli, N.C.; Winter, D.; Leon, H.B.; Filho, H.C.S. Durability, Strength, and Stiffness of Green Stabilized Sand. J. Geotech. Geoenviron. Eng. 2018, 144, 04018057. [CrossRef]

27. Coppola, L.; Bellezze, T.; Belli, A.; Bignozzi, M.C.; Bolzoni, F.; Brenna, A.; Cabrini, M.; Candamano, S.; Cappai, M.; Caputo, D.; et al. Binders alternative to Portland cement and waste management for sustainable construction-Part 2. J. Appl. Biomater. Funct. Mater. 2018, 16, 207-221. [CrossRef] [PubMed]

28. Corrêa-Silva, M.; Miranda, T.; Rouainia, M.; Araújo, N.; Glendinning, S.; Cristelo, N. Geomechanical behaviour of a soft soil stabilised with alkali-activated blast-furnace slags. J. Clean. Prod. 2020, 267, 122017. [CrossRef]

29. Cristelo, N.; Fernández-Jiménez, A.; Castro, F.; Fernandes, L.; Tavares, P. Sustainable alkaline activation of fly ash, aluminium anodising sludge and glass powder blends with a recycled alkaline cleaning solution. Constr. Build. Mater. 2019, 204, 609-620. [CrossRef]

30. Cristelo, N.; Glendinning, S.; Fernandes, L.S.G.; Pinto, A.T. Effect of calcium content on soil stabilisation with alkaline activation. Constr. Build. Mater. 2012, 29, 167-174. [CrossRef]

31. Daassi-Gli, C.A.P. Estabilização de um Solo Granular com Misturas de Pó de Vidro-Cal de Carbureto-Hidróxido de Sódio (NaOH); Federal University of Rio Grande do Sul: Porto Alegre, Spain, 2020.

32. Duxson, P.; Jimenez, A.M.F.; Provis, J.; Lukey, G.C.; Palomo, Á.; Van Deventer, J.S.J. Geopolymer technology: The current state of the art. J. Mater. Sci. 2006, 42, 2917-2933. [CrossRef]

33. Escalante-Garcia, I.J. Overview of potential of urban waste glass as a cementitious material in alternative chemically activated binders. J. Chin. Ceram. Soc. 2015, 43, 1441-1448. [CrossRef] 
34. Fernández-Jiménez, A.; Palomo, A. Composition and microstructure of alkali activated fly ash binder: Effect of the activator. Cem. Concr. Res. 2005, 35, 1984-1992. [CrossRef]

35. Lee, S.; Chung, M.; Park, H.M.; Song, K.-I.; Chang, I. Xanthan Gum Biopolymer as Soil-Stabilization Binder for Road Construction Using Local Soil in Sri Lanka. J. Mater. Civ. Eng. 2019, 31, 06019012. [CrossRef]

36. Liu, Y.; Shi, C.; Zhang, Z.; Li, N. An overview on the reuse of waste glasses in alkali-activated materials. Resour. Conserv. Recycl. 2019, 144, 297-309. [CrossRef]

37. Lotero, A.; Consoli, N.C.; Moncaleano, C.J.; Neto, A.T.; Koester, E. Mechanical Properties of Alkali-Activated Ground Waste Glass-Carbide Lime Blends for Geotechnical Uses. J. Mater. Civ. Eng. 2021, 33, 04021284. [CrossRef]

38. Miranda, T.; Leitão, D.; Oliveira, J.; Corrêa-Silva, M.; Araújo, N.; Coelho, J.; Fernández-Jiménez, A.; Cristelo, N. Application of alkali-activated industrial wastes for the stabilisation of a full-scale (sub)base layer. J. Clean. Prod. 2020, 242, 118427. [CrossRef]

39. Mohajerani, A.; Vajna, J.; Cheung, T.H.H.; Kurmus, H.; Arulrajah, A.; Horpibulsuk, S. Practical recycling applications of crushed waste glass in construction materials: A review. Constr. Build. Mater. 2017, 156, 443-467. [CrossRef]

40. Pinto, A.T. Binding Systems Obtained by Alkaline Activation of Metacaulim; University of Minho: Braga, Portugal, 2004.

41. Bilondi, M.P.; Toufigh, M.M.; Toufigh, V. Using calcium carbide residue as an alkaline activator for glass powder-clay geopolymer. Constr. Build. Mater. 2018, 183, 417-428. [CrossRef]

42. Pourakbar, P.S.; Asadi, A.; Huat, B.B.K.; Cristelo, N.; Fasihnikoutalab, M.H. Application of Alkali-Activated Agro-Waste Reinforced with Wollastonite Fibers in Soil Stabilization. J. Mater. Civ. Eng. 2017, 29, 04016206. [CrossRef]

43. Provis, J.L.; Bernal, S.A. Binder Chemistry—Blended Systems and Intermediate Ca Content; Springer: Singapore, 2014; pp. 125-144.

44. Redden, R.; Neithalath, N. Microstructure, strength, and moisture stability of alkali activated glass powder-based binders. Cem. Concr. Compos. 2014, 45, 46-56. [CrossRef]

45. Rios, S.; Cristelo, N.; Da Fonseca, A.V.; Ferreira, C. Structural Performance of Alkali-Activated Soil Ash versus Soil Cement. J. Mater. Civ. Eng. 2016, 28, 04015125. [CrossRef]

46. Rivera, J.F.; Cuarán-Cuarán, Z.I.; Vanegas-Bonilla, N.; de Gutiérrez, R.M. Novel use of waste glass powder: Production of geopolymeric tiles. Adv. Powder Technol. 2018, 29, 3448-3454. [CrossRef]

47. Rivera, J.F.; Orobio, A.; Cristelo, N.; de Gutiérrez, R.M. Fly ash-based geopolymer as A4 type soil stabiliser. Transp. Geotech. 2020, 25, 100409. [CrossRef]

48. Saldanha, R.B.; Consoli, N.C. Accelerated Mix Design of Lime Stabilized Materials. J. Mater. Civ. Eng. 2016, $28,06015012$. [CrossRef]

49. Saldanha, R.B.; Filho, H.C.S.; Mallmann, J.E.C.; Consoli, N.C.; Reddy, K. Physical-Mineralogical-Chemical Characterization of Carbide Lime: An Environment-Friendly Chemical Additive for Soil Stabilization. J. Mater. Civ. Eng. 2018, 30, 06018004. [CrossRef]

50. Sales, L.F.P. Estudo do Comportamento de Fundações Superficiais Assentes em Solos Tratados; Fedral University of Rio Grande do Sul: Porto Alegre, Spain, 1998.

51. Filho, H.C.S.; Saldanha, R.B.; Da Rocha, C.G.; Consoli, N.C. Sustainable Binders Stabilizing Dispersive Clay. J. Mater. Civ. Eng. 2021, 33, 06020026. [CrossRef]

52. Filho, H.C.S.; Sacco, R.L.; Consoli, N.C. The effect of grain size of ground glass particles on the strength of green stabilized sand. Soils Rocks 2020, 43, 669-677. [CrossRef]

53. Thomé, A.; Donato, M.; Consoli, N.C.; Graham, J. Circular footings on a cemented layer above weak foundation soil. Can. Geotech. J. 2005, 42, 1569-1584. [CrossRef]

54. Torres-Carrasco, M.; Puertas, F. Alkaline Activation of Different Aluminosilicates as an alternative to Portland Cement: Alkali Activated Cements or Geopolymers. Rev. Ing. Constr. 2017, 32, 5-12. [CrossRef]

55. Yip, C.K.; Lukey, G.C.; Van Deventer, J.S.J. The coexistence of geopolymeric gel and calcium silicate hydrate at the early stage of alkaline activation. Cem. Concr. Res. 2005, 35, 1688-1697. [CrossRef]

56. Zhang, Z.; Tao, M. Durability of Cement Stabilized Low Plasticity Soils. J. Geotech. Geoenviron. Eng. 2008, 134, 203-213. [CrossRef] 